\title{
The mysteries of nitrogen balance
}

\author{
J. C. Waterlow \\ Human Nutrition Unit, London School of Hygiene \& Tropical Medicine, \\ 50 Bedford Square, London WC1B 3DP, UK
}

\begin{abstract}
The first part of this review is concerned with the balance between $\mathrm{N}$ input and output as urinary urea. I start with some observations on classical biochemical studies of the operation of the urea cycle. According to Krebs, the cycle is instantaneous and automatic, as a result of the irreversibility of the first enzyme, carbamoyl-phosphate synthetase 1 (EC 6.3.5.5; CPS-I), and it should be able to handle many times the normal input to the cycle. It is now generally agreed that acetyl glutamate is a necessary co-factor for CPS-1, but not a regulator. There is abundant evidence that changes in dietary protein supply induce coordinated changes in the amounts of all five urea-cycle enzymes. How this coordination is achieved, and why it should be necessary in view of the properties of the cycle mentioned above, is unknown. At the physiological level it is not clear how a change in protein intake is translated into a change of urea cycle activity. It is very unlikely that the signal is an alteration in the plasma concentration either of total amino- $\mathrm{N}$ or of any single amino acid. The immediate substrates of the urea cycle are $\mathrm{NH}_{3}$ and aspartate, but there have been no measurements of their concentration in the liver in relation to urea production. Measurements of urea kinetics have shown that in many cases urea production exceeds $\mathrm{N}$ intake, and it is only through transfer of some of the urea produced to the colon, where it is hydrolysed to $\mathrm{NH}_{3}$, that it is possible to achieve $\mathrm{N}$ balance. It is beginning to look as if this process is regulated, possibly through the operation of recently discovered urea transporters in the kidney and colon. The second part of the review deals with the synthesis and breakdown of protein. The evidence on whole-body protein turnover under a variety of conditions strongly suggests that the components of turnover, including amino acid oxidation, are influenced and perhaps regulated by amino acid supply or amino acid concentration, with insulin playing an important but secondary role. Molecular biology has provided a great deal of information about the complex processes of protein synthesis and breakdown, but so far has nothing to say about how they are coordinated so that in the steady state they are equal. A simple hypothesis is proposed to fill this gap, based on the self-evident fact that for two processes to be coordinated they must have some factor in common. This common factor is the amino acid pool, which provides the substrates for synthesis and represents the products of breakdown. The review concludes that although the achievement and maintenance of $\mathrm{N}$ balance is a fact of life that we tend to take for granted, there are many features of it that are not understood, principally the control of urea production and excretion to match the intake, and the coordination of protein synthesis and breakdown to maintain a relatively constant lean body mass.
\end{abstract}

\section{Nitrogen balance: Protein metabolism: Urea}

\footnotetext{
Abbreviations: ASS, arginino succinate synthetase; CPS-1, carbamoyl-phosphate synthetase; LBM, lean body mass; N-AG, N-acetyl glutamate; OCT, ornithine transcarbamylase; UT, urea transporter.

Corresponding author: Professor J.C. Waterlow, 15 Hillgate Street, London W8 7SP, UK.
} 


\section{Introduction}

'Experience shows that virtually every detail of living matter serves a physiological purpose.'

Krebs et al. 1973.

'Sixty years after its initial description the physiological role of the urea cycle continues to be the subject of new ideas and new controversies.'

Morris, 1992.

The object of this review is to try to understand how the body achieves and maintains $\mathrm{N}$ balance and constancy of lean body mass (LMB) in the face of quite large variations in protein intake. As my two opening quotations show, this is essentially a physiological question which is not fully understood and has not received much attention in the current or, indeed, in the past literature. The review is divided into two sections, one concerned with the balance between $\mathrm{N}$ input and output, the other with the balance between protein synthesis and breakdown. These two balances are connected through the free amino acid pool (Fig. 1) (Waterlow, 1994). The size of that pool is only allowed to vary within narrow limits, representing a minute proportion of total body N. Therefore it can be assumed that if input and output are in balance, protein synthesis and breakdown must also be in balance. This follows from the steady state flux equation that was proposed 20 years ago (Waterlow et al. 1978): flux (Q)=synthesis $(\mathrm{S})+$ oxidation/excretion $(\mathrm{O})=$ breakdown $(\mathrm{B})+$ input $(\mathrm{I})$. Rearranging, this becomes $\mathrm{I}-\mathrm{O}$ (input - output balance $)=\mathrm{S}-\mathrm{B}$ (protein balance).

\section{The balance of nitrogen input and output}

Since intake is determined by behavioural factors, the direction of causation is quite clear: output must respond to intake. I shall discuss this question under two headings: the biochemical evidence, from experiments in vitro, of how this response is regulated; and physiological or observational evidence of what happens in vivo.

There is some variation in $\mathrm{N}$ output in the faeces, probably depending on the fibre content of the diet; in N loss from the skin, depending on climate (Ashworth \& Harrower, 1967); and in urinary $\mathrm{NH}_{3}$ output, depending on acid-base status. However, as has been known for nearly 100 years, the major variable is urea (Folin, 1905). The regulation of urea production is therefore the key to $\mathrm{N}$ balance.

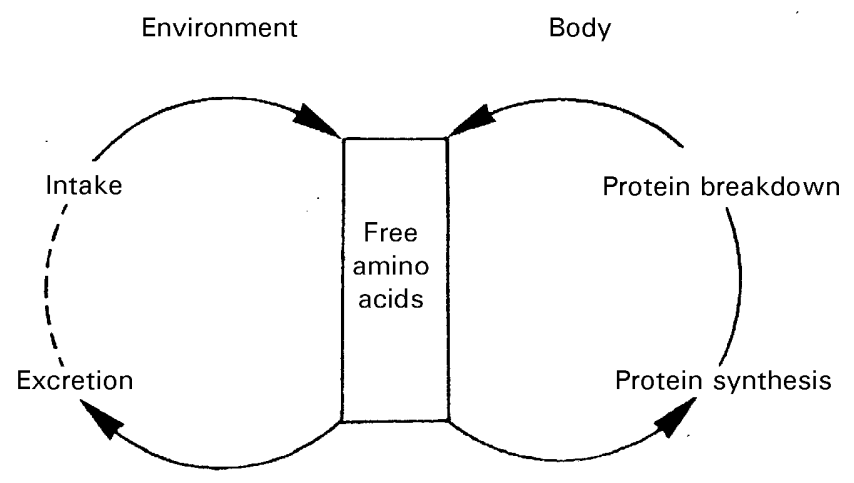

Fig. 1. The twin cycles of nitrogen balance: the cycle of input and output and the cycle of protein synthesis and breakdown, connecting through the free amino acid pool. From Waterlow (1994). 


\section{The biochemical evidence}

Short-term regulation of urea production. The ornithine cycle of urea synthesis discovered by Krebs \& Henseleit (1932) 66 years ago has stood the test of time. In humans and rats the starting-point of the cycle is the supply of $\mathrm{N}$ from amino acids. In ruminants, which have been the subject of many investigations (e.g. Lobley et al., 1995, 1996), the situation is rather different because large amounts of $\mathrm{NH}_{3}$ are presented to the liver as a result of bacterial decomposition in the rumen. I shall not consider them in this review.

Almost all biochemical studies on the details of the urea cycle have been done on rats, but it is presumed that humans behave in the same way. The volume of relevant biochemical work is very large: the review by Meijer et al. (1990) contains over 600 references! It is not easy to compare and put together the results of even a small number of these studies, because they differ so much in experimental design and technical details. Experiments have been done on the whole animal, perfused liver, isolated hepatocytes and mitochondria; in the whole animal the supply of substrate ranges from rapid injection of amino acids (Stewart \& Walser, 1980) to normal feeding for varying periods; in vitro there are differences in the range and concentration of substrates provided and in methods of measurement (e.g. Lund \& Wiggins, 1984). I shall attempt to provide a short overview which I hope will represent a consensus.

First, however, it is necessary to consider a fundamental question raised by Atkinson about the physiological function of the cycle. In his view 'ureagenesis is functionally useful not because it furnishes urea but because it disposes of bicarbonate' (Atkinson \& Bourke, 1984). In support of this view it was shown in hepatocytes that acidosis decreases urea formation and increases that of glutamine, thus sparing bicarbonate for rectifying the acidosis. Haussinger (1983) demonstrated that there is a spatial separation in the liver lobule between urea synthesis and glutaminase (EC 3.5.1.2) activity in periportal cells and glutamine synthesis in perivenous cells. They confirmed the effects of acidosis on the formation of urea and glutamine and concluded from studies on the perfused liver that 'a hepatic intercellular glutamine cycle between periportal and perivenous cells of the lobule serves a regulatory function in the $\mathrm{pH}$ homoeostasis of the organism' (Haussinger et al. 1984). The picture is further complicated by the demonstration in hepatocytes that mitochondria contain carbonic anhydrase ( $E C$ 4.2.1.1.), and an inhibitor of this enzyme, while blocking the production of bicarbonate from $\mathrm{CO}_{2}$, strongly reduces urea production (Dodgson \& Forster, 1986). These results suggest that urea synthesis is not normally dependent on extra-mitochondrial bicarbonate produced by amino acid catabolism.

All these results were obtained in hepatocytes or perfused livers. In the whole animal the picture seems to be rather different. Halperin et al. (1986) infused acid, ammonium salts and bicarbonate into rats and found that neither plasma $\mathrm{pH}$ nor bicarbonate affected the rate of urea synthesis, which depended primarily on the ammonium load. Moreover, they point out that patients with liver failure or congenital absence of urea-cycle enzymes do not suffer from severe metabolic alkalosis. This discrepancy between results in the whole animal and in liver preparations has not, to my knowledge, been resolved. Since we are concerned here primarily with the whole animal, it seems clear to me that the main function of the urea cycle is to preserve $\mathrm{N}$ homoeostasis. If along the way urea formation contributes to the maintenance of acid-base balance, we must regard it as an exceptionally successful and economical piece of physiological engineering.

The components of the urea cycle, as I shall call it rather than the ornithine cycle, will be familiar but some points need special emphasis. Krebs (1973) gives an interesting account of the history of his thinking that led to the discovery of the first true metabolic cycle. He regarded the operation of the cycle as instantaneous and automatic, in the sense that the flux through it is 
determined solely by the kinetic characteristics of the component enzymes and metabolites. Duda \& Handler (1958), pioneers, after Schoenheimer, in the application of ${ }^{15} \mathrm{~N}$ to metabolic studies, took the same view. The substrates of the first enzyme in the cycle, carbamoylphosphate synthetase 1 (EC 6.3.5.5; CPS-1) are $\mathrm{NH}_{3}, \mathrm{HCO}_{3}$ and ATP. $\mathrm{HCO}_{3}$ is always available and there is no competition for ATP, since Hems et al. (1966) showed that a maximal rate of urea synthesis did not interfere with a maximal rate of gluconeogenesis. In fact 6 moles of ATP are formed per mole of urea synthesized (from the oxidation of NADH generated by oxidative deamination of glutamate and regeneration of aspartate from fumarate), with only 4 moles consumed for urea synthesis.

Ammonia enters the cycle in the form of $\mathrm{NH}_{3}$ which, rather than $\mathrm{NH}_{4}^{+}$, is the true substrate (Cohen et al. 1985). Since the equilibrium between $\mathrm{NH}_{3}$ and $\mathrm{NH}_{4}^{+}$is strongly $\mathrm{pH}$ dependent, the control of $\mathrm{pH}$ at the site of urea synthesis must be very tight. Whether $\mathrm{pH}$ plays a regulatory role in $\mathrm{NH}_{3}$ availability and how this fits in with the data and views of Atkinson \& Bourke (1984) and Haussinger (1993) discussed earlier is not clear however. The major precursor of $\mathrm{NH}_{3}$, apart from that which reaches the liver directly from the gut, is glutamate, through the action of glutamate dehydrogenase (EC 1.4.1.2) (Krebs, 1972; Krebs et al. 1976). The glutamate is derived by transamination from alanine, aspartate and other transaminating amino acids. Other sources of $\mathrm{NH}_{3}$, such as the degradation of glutamine, are ruled out as major players because their rate of supply is too low (Krebs et al. 1973). The virtually instantaneous rate of these reactions, both among the precursors of $\mathrm{NH}_{3}$ and in the urea cycle itself, has been confirmed by Cooper et al. $(1987,1988)$ in experiments with the very short-lived isotope ${ }^{13} \mathrm{~N}$. Within seconds of intraportal injection of ${ }^{13} \mathrm{NH}_{3}$, the isotope was widely distributed among the components of the glutamate dehydrogenase, aspartate aminotransferase (EC 2.6.1.1) and alanine aminotransferase (EC 2.6.1.2) reactions. Only a small fraction of the portal-derived $\mathrm{NH}_{3}$ entered glutamine. When $\left[{ }^{13} \mathrm{~N}\right]$ alanine was injected, after $60 \mathrm{~s} 24 \%$ of the isotope had appeared in urea (Cooper et al. 1988). The net $t_{1 / 2}$ for conversion of $\mathrm{NH}_{3}$ to urea was calculated to be $10-11 \mathrm{~s}$. Qualitatively similar results were obtained by Patterson et al. (1995) and by Weijs et al. (1996). Patterson's group gave ${ }^{15} \mathrm{NH}_{4} \mathrm{Cl}$ by mouth and calculated the initial rate of ${ }^{15} \mathrm{~N}$ uptake from the exponential slopes of labelling of various metabolites. Nearly $50 \%$ of the label was taken up into urea, compared with $20 \%$ into arginine and $12 \%$ into each of the two $\mathrm{N}$ atoms of glutamine. The extent of these interchanges, though not their rate, has also been confirmed by measurements of ${ }^{15} \mathrm{~N}$ by NMR (Geissler et al. 1992).

The question has been raised as to how the stoichoimetry is achieved between the two $\mathrm{N}$ atoms of urea derived from $\mathrm{NH}_{3}$ and aspartate. Krebs (1976) and Krebs et al (1976) explained it on the basis that aspartate aminotransferase is a very abundant enzyme which operates near to equilibrium. Aspartate is always present in excess and as fast as it is used up in the formation of argininosuccinate it is replenished. Its rate of supply for urea formation is therefore automatically determined by the activity of CPS- 1 .

On the basis of this evidence from experiments in vitro it is reasonable to regard the operation of the urea cycle as automatic, controlled entirely by kinetic and thermodynamic factors. The first enzyme, CPS-1, operates far from equilibrium, it is not reversible, and it exerts almost $100 \%$ of control of the flux through the cycle (Wanders et al. 1984). The system as a whole is capable of handling a wide range of $\mathrm{NH}_{3}$ supply, the concentrations of intermediates are kept low, and the cycle is usually operating at only a fraction of its capacity (Meijer et al. 1990). As Krebs et al. (1973) put it: 'The capacity of the cycle is always large enough to remove promptly any surplus N'.

However, CPS- 1 has for its activity an absolute requirement for a co-factor, $\mathrm{N}$-acetyl glutamate (N-AG). N-AG is an allosteric activator of CPS-1 and it does not affect the catalytic properties of the 
enzyme; the free enzyme is inactive, the CPS-1-N-AG complex is fully active and is, in fact, the functional catalytic unit (Cheung \& Raijman, 1980). There has been much discussion and much controversy about the possible role of N-AG as a regulator or controller of the urea cycle. The synthesis of N-AG is stimulated by glutamate, through a substrate effect (Stewart \& Walser, 1980), and also by arginine (Krebs et al. 1973; Shigesada \& Tatibana, 1978). The amount of NAG in the liver increases when the supply of $\mathrm{N}$ is increased, as does the production of urea. Discussion, on the whole, has centred round the time-relationships of the increases that have been found in different experimental situations. Obviously if the rise in N-AG followed the rise in urea production it would be difficult to argue for its having a causal or controlling role.

Many authors have inclined to the view that N-AG does regulate urea synthesis (McGivan et al. 1974, 1976; Shigesada \& Tatibana, 1978; Saheki et al. 1980). Stewart \& Walser (1980) gave amino acids intraperitoneally and showed that a rise in N-AG occurs within minutes. It is an attractive hypothesis that glutamate stimulates the formation of N-AG which then exerts control over CPS-1. On the other hand, in a more physiological type of experiment BeliveauCarey et al. (1993) studied metabolite concentrations in the livers of rats during a meal preceded by $20 \mathrm{~h}$ fasting. They concluded that $\mathrm{N}-\mathrm{AG}$ is not the only determinant of the state of activation of CPS-1; rather, in vivo, moment-to-moment control of the rate of urea formation is exerted by substrate availability. A similar statement of the relationship was given by Cohen et al. (1987): 'Moment-to-moment regulation of citrulline and urea synthesis in vivo is brought about primarily by changes in the concentrations of free $\mathrm{NH}_{3}$ and ornithine. Changes in the liver concentration of N-AG, which occur more slowly, set the range of activity of CPS-1, within which $\mathrm{NH}_{3}$ and ornithine exert immediate control in a given nutritional situation'. Other relevent papers, generally supporting this conclusion, are those of Cheung \& Raijman et al. (1980) and Meijer et al. (1985).

This is a complex subject, but in the context of the control of $\mathrm{N}$ balance it is important to establish whether N-AG is a regulator, or an an essential co-factor. It seems that this controversy remains unresolved.

Other possible regulators have to be considered briefly. Ornithine could in theory exert substrate control on the activity of ornithine transcarbamylase (EC 2.1.3.3; OCT); experimental situations can be devised in which ornithine is rate-limiting, but apparently this does not happen in vivo; if it did, carbamoyl phosphate would accumulate, and this has not been observed. In studies on urea synthesis the concentration of carbamoyl phosphate has never been related to the urea flux (Meijer et al. 1985, 1990). The concentration of carbamoyl phosphate remains very low however fast the cycle is turning. Ornithine may, however, have an indirect role through increasing the concentration of its product, arginine, and thus stimulating the synthesis of N-AG (Krebs et al. 1973; Shigesada et al. 1978).

It has been suggested that argininosuccinate synthetase (EC 6.3.4.5; ASS) might be ratecontrolling because it is the least abundant, in terms of activity per g liver, of all the urea-cycle enzymes. It is only when all substrates are in excess that ASS activity may be limiting. Moreover, in the experiments of Saheki et al. (1980) the concentration of urea in the liver rose before there was any increase in ASS; when urea synthesis was stimulated by an injection of $\mathrm{NH}_{4} \mathrm{Cl}$, ASS activity did not change.

A final possibility is that urea synthesis might be limited by the rate of transport of substrates from the mitochondria to the cytoplasm. It was found that citrulline synthesized in the mitochondria was passed along a channel in the cytoplasm, so that in labelling experiments the urea formed reflected the labelling in the mitochondria and not in the cytoplasm (Cohen et al. 1987; Watford, 1989). Cheung et al. (1989) showed that the three extra-mitochondrial enzymes did not move freely in the cytoplasm but are grouped round the mitochondria. The work of 
Hesketh (1996) on targetting of mRNA to different regions of the cytoplasm is clearly very relevant here. It has also been suggested that glutamate transport, which requires a special transporter, could be rate-limiting (McGivan et al. 1974).

In my opinion the balance of evidence is in agreement with Krebs' view, i.e. control of urea production by $\mathrm{NH}_{3}$ concentration at the site of CPS-1 activity. N-AG is a necessary co-factor, but it does not regulate. Only if the activity of CPS-1 is very high may the supply of ornithine become limiting (Cohen et al. 1987). It is interesting that long before the spate of biochemical studies in the 1970s and 1980s, Duda \& Handler (1958) expressed exactly the same view, based on their pioneering studies with $\left[{ }^{15} \mathrm{~N}\right]$ ammonium. They say: ' ... the rate of urea synthesis over the entire range (of dosage) was dependent solely on the available substrate, and neither the necessary enzymes nor coenzymes seemed to limit the synthetic rate ... Assuming that the linear relationship between ammonia concentration and urea synthesis observed here obtains at the still lower ammonia concentration of the normal steady state, urea synthesis and hence nitrogen balance must be governed by those factors which determine $\mathrm{NH}_{3}$ concentration'.

The only weak point in the argument is that there is virtually no information about variations in free $\mathrm{NH}_{3}$ concentration which could be correlated with variations in urea synthesis. The reason is the difficulties of measurement (Cohen et al. 1985). $\mathrm{NH}_{3}$ concentration calculated from $\mathrm{NH}_{4}$ concentration at physiological $\mathrm{pH}$, and assuming an appropriate value for the $\mathrm{p} K$, was about $5 \mu \mathrm{M}$, which is almost two orders of magnitude less than total $\mathrm{NH}_{4}$ concentration. This kind of calculation is unlikely to give accurate results for very minute changes in $\mathrm{NH}_{3}$ concentration. Brown et al. (1957) determined $\mathrm{NH}_{3}$ concentration in the livers of rats by the Berthelot reaction which measures free $\mathrm{NH}_{3}$. At $10 \mathrm{~s}$ after the rats were killed, $\mathrm{NH}_{3}$ concentration was $0.08 \mathrm{mg} \mathrm{N} / \mathrm{g}$ liver. At $20 \mathrm{~s}$ the concentration had doubled as a result of hydrolysis of glutamine. Perhaps the problem could be overcome by the use of ${ }^{15} \mathrm{~N}$ tracers and detection by NMR (Geissler et al. 1992). It may be for this kind of technical reason that when Beliveau-Carey et al. (1993) analysed the livers of rats fed a meal after $20 \mathrm{~h}$ fasting, they found no relation between the concentration of total $\mathrm{NH}_{3}$ and the increase in urea, although there were marked increases in alanine and glutamate. This is the most physiological of all the experiments in the field.

Duda \& Handler (1958) suggested that the free $\mathrm{NH}_{3}$ concentration might be virtually zero. Indeed, if the urea cycle operates in such a way that the rate of production of carbamoyl phosphate exactly equals the rate of $\mathrm{N}$ supply, the substrate concentration would remain constant. However, it has been pointed out by M Brand (personal communication) that in such a situation there must be a message passed from an outside source to signal that the cycle has to go faster or more slowly. This message could be N-AG but, as discussed above, that seems to be questionable. The alternative would be an exquisite sensitivity of the cycle to minute changes in concentration, as implied by Krebs. This constitutes one of the mysteries of the regulation of $\mathrm{N}$ balance which has yet to be solved.

Long-term regulation of urea-cycle enzymes. In the 1960s and 1970s there was great interest in the induction and repression of enzymes, defined by Kenney (1970) as a change in the amount of an enzyme produced by a change in the rate of its synthesis. Krebs (1972) gives a list of amino acid degrading enzymes and the extent to which they could be induced. Particular attention was given to tyrosine aminotransferase, ornithine aminotransferase (EC 2.6.1.68), tryptophan pyrrolase (EC 1.13.11.11) and serine dehydratase (EC 4.2.1.13), presumably because they are highly inducible, in some cases 50 -fold, and therefore particularly suitable for the study of nutritional and hormonal effects. Corticosteroids, glucagon and c-AMP emerged as powerful inducers, while insulin and glucose usually had the opposite effect. For a review of this old work, see Kenney (1970). 
In 1962, Schimke published his classical paper on the adaptation of urea-cycle enzymes in the rat to different levels of dietary protein $(150,300$, and $600 \mathrm{~g} / \mathrm{kg}$ diet $)$. This work also included measurements on enzymes which provide $\mathrm{NH}_{3}$ for uptake into the cycle. Das \& Waterlow (1974) made somewhat similar experiments, with particular attention to the timecourse of the enzyme changes during the period of adaptation to a new level of protein intake.

There have been further studies since then; for an up-to-date review, see Morris (1992). It is difficult to make comparisons because of differences in experimental design, levels of protein fed, timing of the measurements, etc., but the salient finding is that with increasing dietary protein the activity of all the enzymes increased and to very much the same extent (2-3-fold), with arginase (EC 3.5.3.1) lagging a little behind. With a protein-free diet the opposite changes occurred (Schimke, 1962b). Starvation, on the other hand, led to a doubling of urea output with a more than 2-fold increase in the activity of the enzymes, again except for arginase (Schimke, 1962b; Felipe et al. 1991). In another experiment Barber et al. (1985) compared in rats the effects of a chow diet and a 'cafeteria' diet, which has been much used to produce obesity in rats. On equal $\mathrm{N}$ intakes the cafeteria-fed rats produced less urea and showed a decrease in the activity of all the urea-cycle enzymes. These rats were gaining weight, with presumably some gain in LBM, so the experiment suggests that the changes in enzyme activity were related to the $\mathrm{N}$ available for urea production rather than to the $\mathrm{N}$ intake. All these experiments on the activity of liver enzymes were made in rats. In a study on malnourished children, liver samples were obtained by biopsy before and after recovery (Stephen \& Waterlow, 1968). In the malnourished state ASS, which was then considered to be the rate-limiting enzyme, was reduced and the activity of the 'amino acid activating enzymes', as the amino acyl t-RNA synthetases were then called, was increased, in agreement with earlier findings in rats (Mariani et al. 1963). Such studies would not now be considered justifiable, although in our hands there were never any complications from the biopsies.

The time-course of the enzyme changes is important. Our experiments (Das \& Waterlow, 1974) were specifically directed to this point. We found in rats that on changing the diet from 145 to $45 \mathrm{~g}$ casein $/ \mathrm{kg}$ diet or vice versa, a new steady state both in $\mathrm{N}$ output and enzyme activity was reached in $30 \mathrm{~h}$. The three cytoplasmic enzymes of the urea cycle were measured, together with three that feed $\mathrm{N}$ into the cycle: alanine and aspartate aminotransferases and glutamate dehydrogenase. All the enzymes responded in a very similar way and at very similar rates, with net $t_{1 / 2}$ of about $8 \mathrm{~h}$, whether the $\mathrm{N}$ intake was increased or decreased, although with the upward change there was a short lag-period. The rapidity of these changes contrasts with the observations of other workers on the time needed to achieve a new steady state after the $\mathrm{N}$ intake has been changed: $3 \mathrm{~d}$ for ASS and $5 \mathrm{~d}$ for arginase (Szepesi \& Friedland, 1969); 4-8d for OTC and arginase (Schimke, 1962a); 20-30 d for CPS-1 and aspartate aminotransferase (Felipe et al. 1991). Some authors reported that urea excretion and N-AG concentration in the liver responded much more rapidly to changes in the diet than the urea-cycle enzymes, within hours rather than days (Stewart \& Walser, 1980; Saheki et al. 1980; Felipe et al. 1991). It is difficult to explain these differences in the rate of response; perhaps they arise simply from differences in experimental design. However that may be, from our own experiments (Das \& Waterlow, 1974) we naively drew the conclusions that the changes in enzymes caused the changes in urea output. It now looks as if the direction of causality may be the opposite.

It is accepted that the changes in enzyme activity are brought about by changes in amounts of the enzyme proteins (Schimke, 1964; Nicoletti, 1977; Tsuda et al. 1979; Saheki et al. 1980; Mori et al. 1981; de Groot et al. 1984). There seems to be no evidence for allosteric effectors, except for N-AG, nor of activity being controlled by phosphorylation/dephosphorylation, as with the branched-chain amino acid dehydrogenases (Randle, 1984; Harris et al. 1986). 
Schimke (1964) was again the pioneer in studies of the rates of synthesis and degradation of the urea-cycle enzymes, concentrating initially on arginase, and using a combination of immunological and isotopic methods. Full details of the methods and their theoretical basis are to be found in Schimke (1970). Other studies followed: by Chee \& Swick (1976) on the turnover rate of ornithine aminotransferases; by Nicoletti et al. (1977) on that of CPS-1; and by Tsuda et al. (1979) on that of ASS. The overall conclusions from this work may be summarized as follows: in the steady state the rates of synthesis and breakdown are, by definition, equal but what is surprising is that the rates are the same, regardless of the level of protein intake. During a period of dietary transition the main change is in the rate of synthesis, as predicted by Kenney (1970), with smaller or no changes in degradation. The steady-state degradation rates found in these experiments fall within the range of $0 \cdot 09-0 \cdot 3 / \mathrm{h}$, which is slower than the rates of the highly inducible enzymes such as tyrosine aminotransferase (EC 2.6.1.5) or tryptophan pyrrolase, but in line with many other liver enzymes (Waterlow et al. 1978). The concentrations of the mRNA for these enzymes were found to increase with increases in their amounts and activity (Mori et al. 1981; Morris et al. 1987), which suggests regulation of gene expression and transcription (Jackson et al. 1986), but later work indicated that the situation is more complicated, with different control mechanisms for the different enzymes (Ulbright \& Snodgrass, 1993). How the activities of the two mitochondrial and three cytoplasmic enzymes are coordinated is, as far as I know, unknown. The fact that four of the five genes are on separate chromosomes (Jackson et al. 1986) makes this coordination all the more remarkable. The suggestion that it is all brought about by glucocorticoids and glucagon working through cyclic AMP seems rather simplistic (de Groot et al. 1984).

Here I leave this subject, with a question posed in the spirit of Krebs' remark at the beginning of this review: what is the purpose or reason for the 2-3-fold increase in activity of the enzymes with quite a modest increase in protein intake (e.g. Das \& Waterlow, 1974), when from biochemical evidence it seems that the urea cycle could easily handle such an increase in load without any help from enzyme induction? If these enzyme inductions also occur in man, as our evidence suggests that they do, then could it be a hangover from the time when the huntergatherers' diet was much higher in protein than it is now (Speth, 1989), interspersed with episodes of hunger? This is another mystery.

\section{The physiological evidence}

When the dietary protein intake is changed, for $\mathrm{N}$ output to match the new level of intake takes 7-10d in adult men (Martin \& Robison, 1922; Rand et al. 1976, 1979), 2-3d in the infant (Chan, 1968) and, as we have seen, about $30 \mathrm{~h}$ in the rat (Das \& Waterlow, 1974). During this time, if the shift is from a high to a low intake, there are small but decreasing losses of body $\mathrm{N}$, amounting to $2-3 \%$ of the total. There are limits to the range of intakes over which this adaptation occurs. The lower limit of intake is fixed by the rate of obligatory $\mathrm{N}$ loss corrected for the efficiency of utilization. If the intake is below this, there will be a continuing loss of LBM until a new balance can be achieved when the low intake can maintain a lower body mass (Waterlow, 1985). Thus there are two phases of adaptation: in the first the loss of LBM is regarded as trivial, although no one knows whether it has any functional consequences. About 30-40 years ago there was much discussion about protein reserves, protein stores or 'labile protein', which were supposed to provide the extra $\mathrm{N}$ excreted during this period of negative balance. However, no such protein stores have ever been identified and it is better to regard the process as part of a time-lag in adaptation. Indeed it may be eventually replenished as part of the adaptation process. This is suggested by the fact that within otherwise healthy 
well-nourished populations, individual subjects consume varying protein intakes which do not appear to influence the LBM when the intakes vary within the normal range. In the second phase of adaptation the loss of LBM associated with very low intakes would be regarded as unacceptable. The concept of $\mathrm{N}$ balance is therefore married to the concept of maintaining an 'acceptable' LBM. The upper limit of $\mathrm{N}$ balance is much harder to define. It may well be, as Millward (1995) has suggested, that there is a protein-stat mechanism for the regulation of the LBM which includes a set-point for the skeletal muscle component which the body strives to achieve and maintain and which is physiologically and biochemically difficult to exceed. This is certainly the case for individual proteins such as plasma albumin and, under normal conditions, haemoglobin.

In contrast to these longer-term adaptations of $\mathrm{N}$ balance, there are also short-term diurnal fluctuations in both urea excretion and $\mathrm{N}$ balance. A good example is a study by Steffee $e t$ al. (1981). There was a well-marked periodicity of urea excretion in subjects receiving $1.5 \mathrm{~g}$ protein $/ \mathrm{kg}$ per $\mathrm{d}$ in 4-hourly meals from 08.00 to 22.00 hours. If one allows for the slow turnover rate of the urea pool, the peak excretion corresponded quite well with the period of feeding, and the nadir with the period of fasting. The periodicity was preserved on low protein intakes of $0 \cdot 1 \mathrm{~g} / \mathrm{kg}$ per $\mathrm{d}$, but with a lesser amplitude.

Further evidence on the extent of the changes in $\mathrm{N}$ excretion and $\mathrm{N}$ balance produced by feeding protein comes from studies on diurnal changes in protein balance, synthesis and breakdown over $12 \mathrm{~h}$ periods of alternate fasting and feeding (Pacy et al. 1994; Price et al. 1994; Quevedo et al. 1994). Fig. 2(a) shows the urea excretion rates (corrected for changes in the body-N pool) over $12 \mathrm{~h}$ feeding and fasting periods in subjects adapted over 2 weeks to varying protein intakes. Over a 6fold range of protein intakes $(0.36-2.3 \mathrm{~g} / \mathrm{kg}$ per d), daily urea excretion increased by 4 -fold with increases in both fasted and fed states and with the fed rate compared with the fasted rate, increasing by between $9 \%$ on the very low intake to $50 \%$ on the higher intakes.

In these studies measurements were made not only of diurnal changes in $\mathrm{N}$ balance and excretion but an alternative approach to direct measurement of $\mathrm{N}$ excretion or balance was used based on the oxidation of $\left[1-{ }^{13} \mathrm{C}\right]$ leucine. In this case the assumption is made that leucine balance predicts $\mathrm{N}$ balance, assuming a known leucine content of body protein (about $8 \%$ ) so that leucine oxidation will predict $\mathrm{N}$ loss in the fasted state. In the fed state account needs to be taken of the leucine content of the food, and how much of the food is deposited as body protein. Thus with milk, which contains $10 \%$ leucine, there will be an excess of leucine oxidation compared with $\mathrm{N}$ excretion during feeding which will need to be accounted for (el Khoury et al. 1994, 1995b, 1996; Price et al. 1994). On this basis there is reasonable agreement between predicted and measured $\mathrm{N}$ losses. The leucine method demonstrates very clearly the swings between fasting and feeding, and may well be more accurate because measurements can be made over shorter intervals. For example, in one study in which the daily protein intake was $0.77 \mathrm{~g} / \mathrm{kg}$ per $\mathrm{d}$, a negative balance during $12 \mathrm{~h}$ without food was cancelled out by a positive balance during $12 \mathrm{~h}$ with food. These fluctuations round a mean of zero balance amounted to about $50 \mathrm{mg} \mathrm{N} / \mathrm{kg}$ per $12 \mathrm{~h}$, or less than $0.2 \%$ of total body N (Price et al. 1994).

There seem, therefore, to be two methods for regulating $\mathrm{N}$ balance, short-term and longterm, which may operate in combination, as in the experiments of Quevedo et al. (1994) on diurnal changes over $14 \mathrm{~d}$ on moving from a high to a moderate protein intake. In this study daily total urea $\mathrm{N}$ excretion fell by $93 \mathrm{mg} / \mathrm{kg}$ per d over $9 \mathrm{~d}$ (Fig. 2(b)), whereas the difference between $\mathrm{N}$ excretion between feeding and fasting was on average only $37 \mathrm{mg} \mathrm{N} / \mathrm{kg}$ per d and did not change significantly from the beginning to the end of the period of adaptation (Fig. $2(c))$ ! It seems reasonable to suppose that the diurnal adjustments result from the instantaneous regulation of the urea cycle postulated by Krebs, whereas the longer-term larger adaptation is 

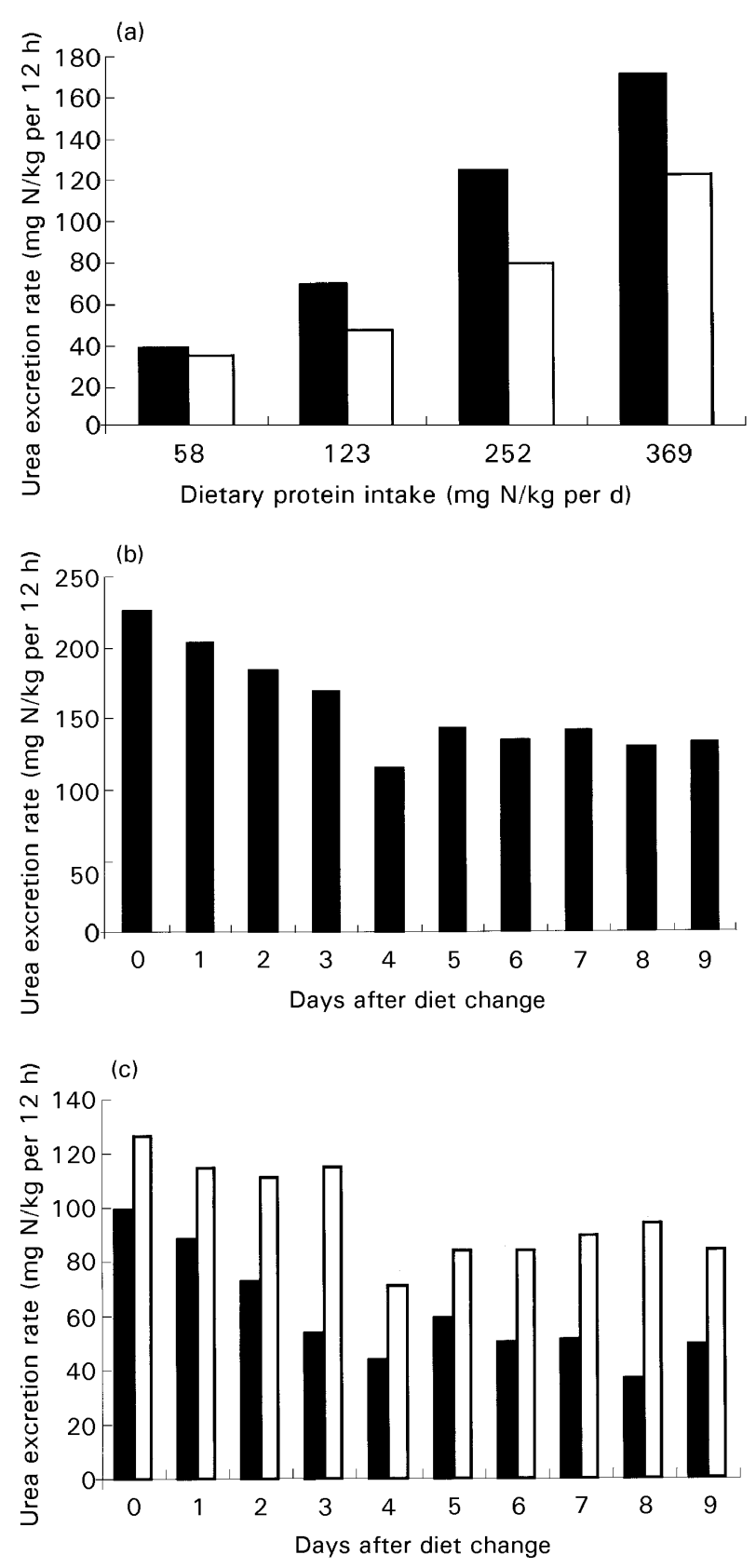

Fig. 2. Urea excretion rates in relation to protein intake. (a) Urea excretion rates (corrected for changes in the body $\mathrm{N}$ pool) over $12 \mathrm{~h}$ feeding $(\square)$ and fasting ( $\square$ ) periods in subjects adapted over 2 weeks to varying protein intakes (recalculated from Price et al. 1994). (b) Daily total urea $\mathrm{N}$ excretion on moving from a high intake (day $0,1.9 \mathrm{~g}$ protein $/ \mathrm{kg}$ per d) to a moderate intake (days $1-9,0.77 \mathrm{~g}$ protein $/ \mathrm{kg}$ per d) (recalculated from Quevedo et al. 1994. (c) Total urea N excretion during $12 \mathrm{~h}$ fasting $(\mathbf{\square})$ or feeding $(\square)$ periods in subjects moving from a high intake (day $0,1.9 \mathrm{~g}$ protein $/ \mathrm{kg}$ per d) to a moderate intake (days $1-9,0.77 \mathrm{~g}$ protein $/ \mathrm{kg}$ per d) (recalculated from Quevedo et al. 1994). 
produced by changes in the enzymes. However, these responses are in fact a mystery. It is not clear why the second mechanism should be necessary, since the difference between the $\mathrm{N}$ intakes on fasting and feeding is just as great as the difference between the extremes of normal protein intake. It is also surprising that there is so little change in the urea excretion during feeding when there is a marked change in intake which occurred on day 1 in Fig. 2(c).

The next question to be considered is the quantitative relationships in the whole animal between N load and urea production. Duda \& Handler (1958) injected increasing amounts of ammonium lactate into rats and found a linear relationship between the dose, up to $6 \mathrm{mmol} / \mathrm{kg}$ (equivalent to $0.525 \mathrm{~g}$ protein $/ \mathrm{kg}$ ), and the amount of urea synthesized in $20 \mathrm{~min}$. Vilstrup (1980, 1989) made a comprehensive study of this relationship in human subjects. He infused amino acids in varying amounts and showed a linear relation between urea production and plasma amino acid concentration. This covered a 6-fold range of urea synthesis of about 40$240 \mathrm{mmol} / \mathrm{h}$, at plasma amino acid levels of 3-12 mM. The results were the same when alanine was infused instead of an amino acid mixture. Similar studies were made by Raforth \& Onsted (1975) in normal men fed different amounts of protein. There was a linear relationship between serum amino acid concentrations and rate of urea production. However, there are marked discrepancies between these two studies in the slopes of the lines and the points at which they cut the amino acid concentration axis, discrepancies which are unexplained. These represent short-term measurements. In the longer term the picture appears to be different, as indicated by two studies of the effects of longer-term change in protein intake on plasma amino acids, which although urea production was not measured would be expected to be associated with quite different rates of urea excretion. Young \& Scrimshaw (1968) and Adibi (1968) both measured postabsorptive plasma amino acid concentrations in young men before and after 1-2 weeks on a protein-free diet, when we know that urea excretion falls markedly (Table 1). In both studies there was a rise in total plasma amino acids, with a small fall in the essential and an increase in the nonessential amino acids. Alanine showed the largest increase. Unfortunately no measurements were made of urea production or excretion at the beginning and end of the period on a low-protein intake. Young \& Scrimshaw (1968) did note that after 7-10 d on the protein-free diet, total urinary $\mathrm{N}$ had fallen to $36 \mathrm{mg} / \mathrm{kg}$ per $10 \mathrm{~d}$ which, of course, is a very low level. A difficulty in comparing these results with those of Vilstrup (1989) is that he was operating at the top end of the range of physiological load, Young \& Scrimshaw (1968) and Adibi (1968) at the bottom end, and the time-scales of the experiments were completely different.

More important are the amino acid concentrations in the liver, which for most of the nonessential amino acids (alanine, glycine, glutamic acid and glutamine) are normally many times higher in liver than in plasma, whereas the concentrations of the essential amino acids are approximately the same (Bergstrom, 1974). Adibi et al. (1973) measured amino acid concentrations in the livers of rats fed on a protein-free diet for $8 \mathrm{~d}$. By that time the concentrations of the branched-chain amino acids had fallen to about $70 \%$ of the initial levels. This is not a very large change, considering the duration and severity of the stress. The message from these human studies as far as they go is that in the adapted state there does not seem to be any relation between amino acid concentrations and urea excretion. However, excretion is not the same as production, as will be discussed in the next section.

\section{The metabolism of urea}

The straightforward concept that urea production is somehow matched to $\mathrm{N}$ intake was complicated by the work of Walser \& Bodenlos (1959) showing that the calculated rate of urea production exceeded the rate of urea excretion by about $20 \%$. All those who have studied the 
Table 1. Effect of a protein-free diet on plasma concentrations of selected amino acids

\begin{tabular}{|c|c|c|c|c|}
\hline & \multicolumn{4}{|c|}{ Plasma concentration of amino acid $(\mu \mathrm{mol} / \mathrm{l})$} \\
\hline & \multicolumn{2}{|c|}{ Adibi (1968) } & \multicolumn{2}{|c|}{ Young \& Scrimshaw (1968) } \\
\hline & Control & $\begin{array}{l}\text { Protein-free } \\
\text { (2 weeks) }\end{array}$ & Control & $\begin{array}{l}\text { Protein-free } \\
\quad(7-10 \mathrm{~d})\end{array}$ \\
\hline $\begin{array}{l}\text { Nonessential: } \\
\text { Alanine } \\
\text { Glycine } \\
\text { Glutamic acid } \\
\text { Total nonessential }\end{array}$ & $\begin{array}{r}387 \\
238 \\
84 \\
1268\end{array}$ & $\begin{array}{r}673 \\
347 \\
116 \\
1785\end{array}$ & $\begin{array}{r}447 \\
319 \\
307 \\
1682\end{array}$ & $\begin{array}{r}776 \\
415 \\
404 \\
2203\end{array}$ \\
\hline $\begin{array}{l}\text { Essential: } \\
\text { Leucine } \\
\text { Isoleucine } \\
\text { Valine } \\
\text { Threonine } \\
\text { Lysine } \\
\text { Total essential }\end{array}$ & $\begin{array}{r}106 \\
51 \\
187 \\
162 \\
204 \\
929^{\star}\end{array}$ & $\begin{array}{r}107 \\
47 \\
164 \\
176 \\
198 \\
887^{\star}\end{array}$ & $\begin{array}{r}166 \\
91 \\
260 \\
233 \\
239 \\
1208\end{array}$ & $\begin{array}{r}140 \\
74 \\
181 \\
217 \\
208 \\
1016\end{array}$ \\
\hline
\end{tabular}

* Excluding tryptophan (not measured).

problem, measuring urea production either with $\left[{ }^{14} \mathrm{C}\right]$ urea or with doubly-labelled $\left[{ }^{15} \mathrm{~N}^{15} \mathrm{~N}\right]$ urea, have confirmed this observation (Hibbert \& Jackson, 1991; Carraro et al. 1993; el Khoury et al. 1994, 1995b, 1996; Forslund et al. 1998). For a summary of work on urea kinetics, see Jackson (1992). The difference between urea production and excretion results from passage of urea into the colon, where it is hydrolysed to $\mathrm{NH}_{3}$ by bacterial urease (EC 3.5.1.5). This process has been intensively studied by Jackson and his colleagues (Hibbert \& Jackson, 1991; Danielsen \& Jackson, 1992; Hibbert et al. 1992; 1995; Jackson, 1992; Langran et al. 1992; Bundy et al. 1993; Meakins \& Jackson, 1996; Child et al. 1997; McClelland et al. 1997; Jackson, 1998), who refer to it as 'salvage'. There has been much discussion about the fate of the $\mathrm{NH}_{3}$ produced in the gut. It is presumed that it is absorbed into the portal tract, reaches the liver and by transamination joins the amino- $\mathrm{N}$ pool. Thereafter its fate will be determined by the partition of the amino-N flux. In a normal subject, on a usual protein intake, about $20 \%$ of the flux is oxidized and about $80 \%$ taken up by protein synthesis. It would be expected, therefore, that the gut-derived $\mathrm{NH}_{3}$ should follow the same pathways in the same proportions, with only a part of it being recycled to form urea. The trouble with this argument is that the $\mathrm{NH}_{3}$ from the gut will only form nonessential amino acids, so the addition will lead to an unbalanced amino acid mixture. However, the hydrolysed urea will only amount to about $50 \mathrm{mg} \mathrm{N}$ ( $25 \%$ of urea $\mathrm{N}$ production) added to a total nonessential amino- $\mathrm{N}$ flux of about $400 \mathrm{mg} \mathrm{N} / \mathrm{d}$; therefore the distortion will not be very great.

In fact the extent of recycling can be checked by measurement of the output in the urine of $\left[{ }^{14} \mathrm{~N}^{15} \mathrm{~N}\right]$ urea, which, in measurements of urea production with $\left[{ }^{15} \mathrm{~N}^{15} \mathrm{~N}\right]$ urea, can only be produced by recycling (Picou \& Phillips, 1972; Jackson et al. 1984). The results in nine studies by Jackson's group show that on average only $17 \%$ of the gut-derived $\mathrm{NH}_{3}$ was recycled back to urea, in good agreement with the amount predicted earlier. An even lower extent of recycling was found by Carraro et al. (1993). There has also been controversy about the fate of the $\mathrm{NH}_{3}$ that is not recycled but retained in the body. The fact that some of the labelled-N can be identified in plasma albumin (Richards, 1972; Varcoe et al. 1975) has given rise to the concept that it is 'utilized', a term vigorously opposed by Walser (1981) on the grounds that there is no net utilization. This is indeed true in the steady state; ${ }^{15} \mathrm{~N}$ from the gut, converted to amino- $\mathrm{N}$, is 
simply substituting for unlabelled amino-N. However, in growing infants or in subjects on lowprotein diets the $\mathrm{N}$ from salvaged urea will contribute to the flux of amino acids available for protein synthesis, just like any other source of non-specific N (see, for example, Snyderman et al. 1962; Tripathy et al. 1970; Kies \& Fox, 1978). Moreover, the proportion of urea production that is salvaged increases in situations where there is an increased demand for $\mathrm{N}$, so it is reasonable to regard salvage as contributing to the body's $\mathrm{N}$ economy when it is needed.

These considerations are peripheral to the question of $\mathrm{N}$ balance. Both excretion and hydrolysis, in absolute terms, increase with increasing urea production. The important point is the relationship of urea production to $\mathrm{N}$ intake. How closely does production respond to changes in intake? Jackson maintains that production is more or less constant, regardless of intake. My recalculation of his data (Fig. 3) shows that there is a statistical relationship, but not a very sensitive one. At low intakes production is greater than intake up to an intake of about $200 \mathrm{mg} \mathrm{N}$, or $1.25 \mathrm{~g}$ protein $/ \mathrm{kg}$ per $\mathrm{d}$. This finding that at low levels urea-N production is greater than $\mathrm{N}$ intake has been strikingly confirmed in a recent study by Sarraceda et al. (1998) in sheep (Table 2).

It may therefore be concluded that over the normal range of protein intakes, if part of the urea produced was not sequestered by salvage it would be impossible to achieve $\mathrm{N}$ balance.

Another interesting point that emerges from the studies both of Jackson's group (Meakins \& Jackson, 1995) and of el Khoury et al. (1996) was that when measurements were made during the fasting-feeding cycle of $24 \mathrm{~h}$, urea production remained relatively constant throughout, urea excretion rose in the day and fell in the night, as would be expected, and hydrolysis changed in the opposite direction. In fact, in el Khoury's experiment (el Khoury et al. 1996) urea hydrolysis was zero during $12 \mathrm{~h}$ of feeding. In short-term measurements of

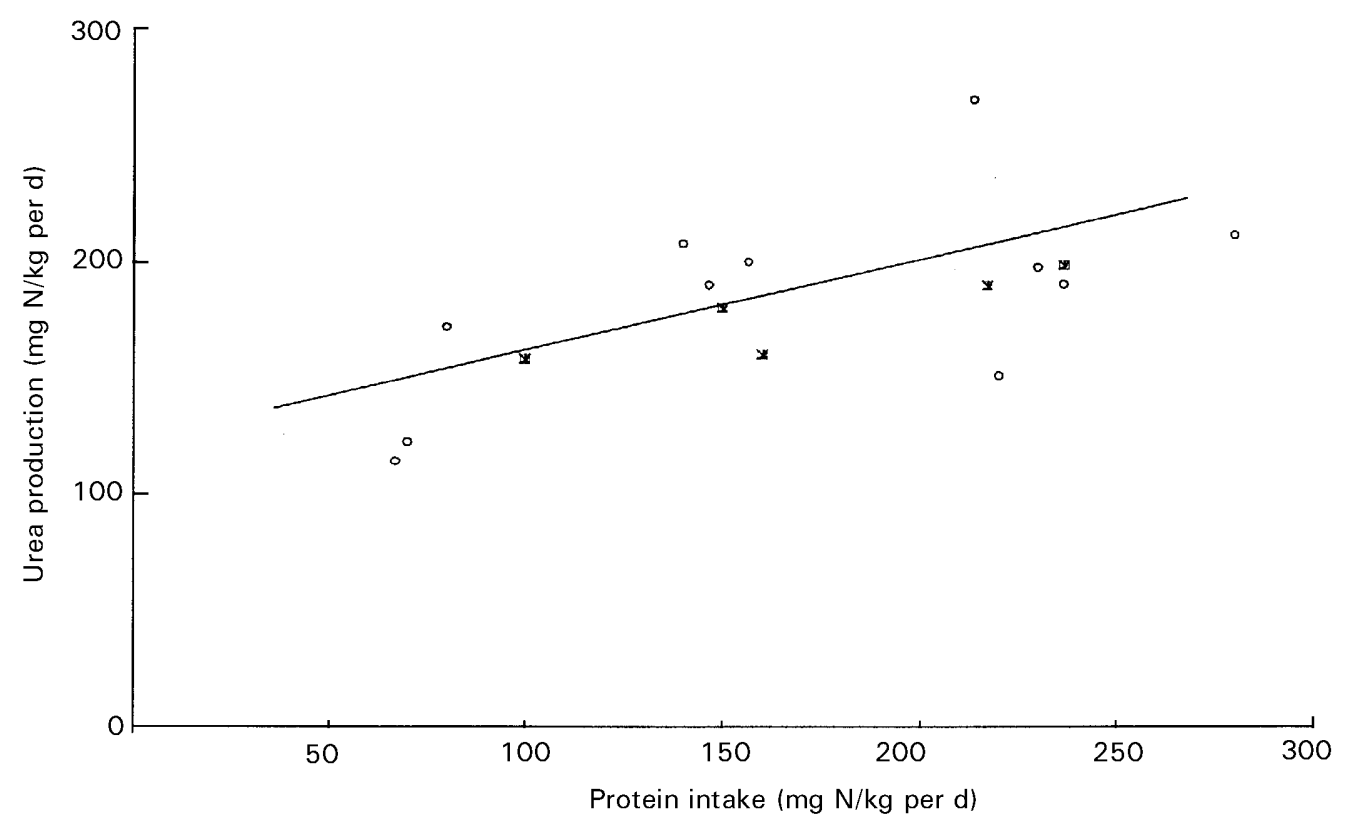

Fig. 3. Urea production in relation to nitrogen intake. Each point is the average of 4-6 subjects. (○), men; (必), women). The line is described by: urea production $(y)=0.33$ intake $(x)+127$, $r=0.61, P<0.05$. Data recalculated from Hibbert \& Jackson (1991); Danielsen \& Jackson (1992); Hibbert et al. (1992, 1995); Jackson (1992); Langran et al. (1992); Bundy et al. (1993); Meakins \& Jackson (1996); Child et al. (1997); McClelland et al. (1997). 
excretion some allowance has to be made for time-lag, unless changes in the body urea pool are determined at the same time, but this will not affect the fact that salvage is periodic, only its timing. The claim by Sarraseca et al. (1998) that Jackson's method overestimates the extent of urea recycling will not affect the results appreciably, since the extent of recycling in man is small (less than $20 \%$ of salvage).

Thus the conclusion from these findings of Jackson and his colleagues is first: that without salvage it would generally be impossible to maintain $\mathrm{N}$ balance; second, that although salvage increases with increasing urea production, the diurnal changes show that it is to a certain extent controlled independently of production.

It is therefore of great interest that a vasopressin-sensitive urea transporter (UT) protein was identified in rat kidney by Knepper \& Star (1990) and the DNA cloned by You et al. (1993) and Smith et al. (1995). It was then found that there are several of these UT proteins present in mammalian tissues. UT2 mRNA is responsive to the state of hydration and UT1 mRNA to changes in the protein content of the diet (Ashkar et al. 1995; Smith et al. 1996). Another UT has recently been isolated from the human colon, and work is now going on to determine its function and homology with other UT. Perhaps this provides a clue to the mechanism by which urea is salvaged. Meanwhile, the control of this process, because it surely must be controlled, is another mystery of $\mathrm{N}$ balance.

\section{The regulation of protein synthesis and breakdown}

The aim in this section is to examine how protein synthesis and breakdown respond to changes in amino acid supply and how the balance between them is achieved. Some boundaries have to be set. I shall deal almost entirely with studies on human adults in vivo, which means mainly, but not exclusively, measurements in the whole body. This is appropriate, because although different tissues may react in different ways to changes in $\mathrm{N}$ intake, in the context of this review we are concerned with the overall response. I have also excluded the vast amount of experimental work on rats, dogs, sheep, goats, etc., because with few exceptions, such as the work of Yu et al. (1990) on liver metabolism in the dog, it does not provide us with any radically different perspectives from studies in humans.

First, a few technical matters have to be considered. The tracer that has been the most widely used by far in studies on humans is leucine labelled in the 1-C position. It was first used by O'Keefe et al. (1974), because it has a small free pool and therefore in infusion experiments will produce an isotopic plateau more quickly, an important point before the use of a priming dose became routine. The next difficulty was that of the precursor, since intracellular dilution of labelled leucine will cause it to have a lower isotope abundance than leucine in plasma. Rennie et al. (1982) and Matthews et al. (1982) solved this problem by using $\alpha$-ketoisocaproic acid as precursor. $\alpha$-Ketoisocaproic acid is the transamination product of leucine, whose labelling

Table 2. Urea recycling in sheep at different levels of protein intake

\begin{tabular}{lrrr}
\hline & & Protein intake & \\
\cline { 2 - 4 } & Low & Medium & High \\
\hline Intake $(\mathrm{g} \mathrm{N} / \mathrm{d})$ & 9.7 & 19.3 & 29.0 \\
Urea-N production $(\mathrm{g} \mathrm{N} / \mathrm{d})$ & 11.5 & 14.8 & 22.4 \\
Urea-N excretion $(\mathrm{g} \mathrm{N} / \mathrm{d})$ & 4.1 & 4.3 & 5.8 \\
Urea-N salvage $(\mathrm{g} \mathrm{N} / \mathrm{d})$ & 7.4 & 10.5 & $16 \cdot 6$ \\
\hline
\end{tabular}

* From Sarraceca et al. (1998). 
presumably reflects that of the intracellular leucine from which it is derived. This is the 'reciprocal pool' method originally proposed by Fern and Garlick (1974) in a different context. Although no single metabolite can ever represent the different levels of labelling in all tissues (Waterlow, 1995), $\alpha$-ketoisocaproic acid probably provides the best available estimate of average precursor activity in the whole body. All this is very well known to workers in the field; what is not so widely recognized is that the use of $\alpha$-ketoisocaproic acid instead of leucine not only increases the estimate of flux and hence the derived values of $S$ (synthesis) and $B$ (breakdown), but also alters their pattern, as can be seen from the example in Table 3 (Hoerr et al. 1993). It must be borne in mind, in considering the tables that follow, that if the use of $\alpha$-ketoisocaproic acid over-estimates the flux it will exaggerate the changes in breakdown.

There are three ways of examining the effect of $\mathrm{N}$ intake on protein synthesis and breakdown. The first is by comparing the findings in subjects adapted to different levels of protein intake; the second is by comparison of results after the transition from fasting to feeding; the third by measuring the changes in a cannulated limb (arm or leg).

\section{Responses of protein synthesis and breakdown}

Different levels of protein intake. The results of such studies as I can find are summarized in Table 4. They are expressed as the ratios of synthesis, breakdown and oxidation at the higher level of protein intake to the corresponding values at the lower level. In all cases the subjects were habituated to the new level for at least $7 \mathrm{~d}$, and all were tested in the fed state.

One cannot make an exact comparison because of the differences in dietary and experimental conditions. Except for the original study by Motil et al. (1981), even with large increases in protein intake synthesis seldom increased by more than $20 \%$. Breakdown was more variable, but generally decreased at the higher protein intakes. Oxidation showed a clearcut increase in every case as the subjects moved to a higher intake, which, under the conditions of these experiments, was usually accompanied by an increased plasma leucine concentration (but see later, p. 40). Young et al. (1985) showed a linear relationship between plasma leucine and oxidation rate. The general impression is that synthesis takes priority and proceeds at a fairly steady rate, while amino acids surplus to the requirements for synthesis are removed by oxidation. This is what one would expect from the $K_{\mathrm{m}}$ of the degradative enzymes, which are many times higher than those of the amino acyl t-RNA transferases (Krebs, 1972; Rogers, 1976; Harper, 1983). The changes in oxidation seem, however, to take 2 or $3 \mathrm{~d}$ to become complete. In the experiment of Motil et al. (1994), on changing the protein content of the diet the change in oxidation by day 2 , relative to day 6 , was $86-93 \%$ complete, depending on the level of protein intake; in the study of Quevedo et al. (1994), in which intake was reduced from 1.8 to $0.77 \mathrm{~g}$ protein $/ \mathrm{kg}$ per $\mathrm{d}$, the reduction in oxidation was only $66 \%$ complete by day 3 , while synthesis remained unchanged throughout, from day 0 to day 14 .

Why should the change in oxidation be so slow, if it depends simply on the properties of the oxidative enzymes? The experiments to be described next show that amino acid oxidation is

Table 3. Effect of choice of precursor on estimates of synthesis and breakdown $(\mu \mathrm{mol} \text { leucine } / \mathrm{kg} \text { per } \mathrm{h})^{\star}$

\begin{tabular}{lcccccc}
\hline Precursor & Flux & Intake & Synthesis (S) & Breakdown (B) & Oxidation & S/B \\
\hline Leucine & 159 & 74 & 106 & 85 & 53 & 1.25 \\
$\alpha$-Ketoisocaproic acid & 196 & 74 & 130 & 122 & 66 & 1.06 \\
\hline
\end{tabular}

${ }^{*}$ Data from Hoerr et al. (1993): intravenous infusions of $\left[1{ }^{13} \mathrm{C}\right]$ leucine in subjects on a high protein intake. 
Table 4. Effect of protein intake, after adaptation, on rates of protein synthesis (S), breakdown (B) and oxidation $(\mathrm{O})$ measured by intravenous infusions of $\left[1-{ }^{13} \mathrm{C}\right]$ leucine. The values are the ratios of the rates of synthesis, breakdown and oxidation at a higher level of protein to those at a lower level

\begin{tabular}{|c|c|c|c|c|}
\hline \multirow{2}{*}{$\begin{array}{l}\text { Protein intake (g/kg per d) } \\
\text { (High/low) }\end{array}$} & \multicolumn{3}{|c|}{$\begin{array}{l}\text { Rate at high protein intake: rate } \\
\text { at low protein intake }\end{array}$} & \multirow[b]{2}{*}{ Reference } \\
\hline & $\mathrm{S}$ & $\mathrm{B}$ & 0 & \\
\hline $\begin{array}{l}0.6 / 0.1 \\
1.5 / 0.6\end{array}$ & $\begin{array}{l}1.59 \\
1.11\end{array}$ & $\begin{array}{l}1.24 \\
0.82\end{array}$ & $\begin{array}{l}1.83 \\
2.09\end{array}$ & Motil et al. (1981) \\
\hline $1 \cdot 5 / 0 \cdot 1$ & $1 \cdot 26$ & $1 \cdot 17$ & 3.83 & Hoerr et al. (1993) \\
\hline $\begin{array}{l}1.5 / 0 \cdot 7^{\star} \\
2.5 / 1 \cdot 5^{\star}\end{array}$ & $\begin{array}{l}1.21 \\
1.07\end{array}$ & $\begin{array}{l}1.19 \\
0.99\end{array}$ & $\begin{array}{l}2.56 \\
1.55\end{array}$ & Goulet et al. (199) \\
\hline $\begin{array}{l}0.77 / 0.36 \\
1.59 / 0.77 \\
2.07 / 1.59\end{array}$ & $\begin{array}{l}1.06 \\
1.18 \\
1.00\end{array}$ & $\begin{array}{l}0.95 \\
0.90 \\
0.69\end{array}$ & $\begin{array}{l}1.56 \\
1.57 \\
1.13\end{array}$ & Pacy et al. (1994) \\
\hline $1.82 / 0.77$ & 1.07 & 0.55 & 1.68 & Quevedo et al. (1994) \\
\hline $\begin{array}{l}2.5 / 1.0 \\
2.72 / 0.63\end{array}$ & $\begin{array}{l}1.13 \\
1.28\end{array}$ & $\begin{array}{l}0.54 \\
0.70\end{array}$ & $\begin{array}{l}2.00 \\
1.48\end{array}$ & $\begin{array}{l}\text { Forslund et al. (1998) } \\
\text { Fereday et al. (1998) }\end{array}$ \\
\hline
\end{tabular}

* Infusions of amino acids after adaptation.

quite capable of adapting very rapidly to changes in intake. In fact, it is quite mysterious why the period of adaptation should take so long.

\section{Fasting and feeding}

In these experiments a continuous infusion is given for periods up to $24 \mathrm{~h}$; during part of the time the subject is in the postabsorptive state and part of the time feeding at intervals of 20$30 \mathrm{~min}$. In the first such study by Clugston \& Garlick (1982) feeding by day was followed by fasting at night, and the results suggested that the main effect of the food was to increase the synthesis rate with little change in breakdown. Later work in which fasting preceded feeding failed to confirm the original finding; Melville et al. (1989) suggested that the discrepancy between feeding-fasting and fasting-feeding arose from recycling during the fasting period of isotope from protein labelled during feeding. Be that as it may, Table 5 summarizes studies in which fasting precedes feeding. The results are expressed as the ratio of rates of synthesis, breakdown and oxidation during feeding to the corresponding rates during fasting.

In general the results are quite similar to those of the longer-term experiments on adaptation to different levels of protein intake. The transition from fasting to feeding produces a small increase in synthesis (average $8 \%$ ) and a larger decrease in breakdown. The higher the protein content of the meal, the bigger the increase in synthesis (S) and decrease in breakdown (B). The results of Pacy et al. (1994) illustrate very clearly Millward's hypothesis that high protein intakes amplify the diurnal swings in synthesis and breakdown, and hence the oscillation between positive and negative $\mathrm{N}$ balance (Price et al. 1994). Again, the increases in oxidation on feeding are large, often more than $50 \%$ above the fasting level. This shows that in spite of the evidence cited earlier for a lag in adaptation, changes in oxidation can occur rapidly and accurately; in most of the experiments in Table 5 the negative balance during fasting is cancelled out by a positive balance during feeding, so that the $24 \mathrm{~h}$ balance is zero.

Since in the feeding phase food is taken orally, it would be more physiological to give the tracer also by the oral route. When this is done, if leucine is the tracer, 20-30\% of it is sequestered by the liver and other portal-drained viscera (the first-pass effect) (Hoerr et al. 
1991, 1993; Matthews et al. 1993). There are, however, only two studies, those of Melville et al. (1989) and Hoerr et al. (1993), in which the data are sufficient to allow a comparison of the results obtained by the two routes. The intra-gastric route gives, as would be expected, higher estimates of flux, synthesis and breakdown. On moving from fasting to feeding (Melville et al. 1989), or from a low- to a high-protein diet (Hoerr et al. 1993), there is a larger increase in synthesis (S) and a smaller decrease in breakdown (B) than when the tracer is given intravenously. Hoerr et al. (1991) say: 'The conclusion that feeding regulates body protein balance mainly through a reduction in whole body protein breakdown needs to be re-evaluated'.

A recent important paper by Cayol et al. (1997) approaches the first-pass effect in a different way. $\left[{ }^{2} \mathrm{H}\right]$ and $\left[{ }^{13} \mathrm{C}\right]$ leucine were infused simultaneously, and the uptake of ${ }^{2} \mathrm{H}$ measured in circulating apolipoprotein B-100. This protein is synthesized in the liver so rapidly that within a few hours its isotope abundance reaches a plateau equal to that of its precursor; it has therefore come to be widely used as a proxy for the true precursor of protein synthesis in the liver (Reeds et al. 1992). Cayol and colleagues constructed a two-pool model which enabled separate estimates to be made of leucine kinetics in the splanchnic and non-splanchnic regions. Using this model they compared the results given by a protein-free formula with one that provided $1.5 \mathrm{~g}$ protein $/ \mathrm{kg}$ per $\mathrm{d}$. The results showed that the dietary protein caused a $30 \%$ increase in whole-body protein synthesis with no change in breakdown. Incidentally, with the high-protein diet there was a 2-fold increase in the absolute rate of albumin synthesis; this recalls the results obtained many years ago by James \& Hay (1968) in children studied with I-labelled albumin.

All the results cited so far assume a steady state which enables synthesis and breakdown to be calculated from the flux (Q) by the classical formula $\mathrm{Q}=\mathrm{S}+\mathrm{O}=\mathrm{B}+\mathrm{I}$ (Waterlow et al. 1978). When the non-steady-state equations of Shipley \& Clarke (1972) were applied to the fastingfeeding data of el Khoury et al. (1995b), taking account of changes in the plasma leucine concentration as a measure of changes in the free leucine pool, the increase in synthesis in response to a meal was substantially greater than that obtained by the usual method of calculation (Waterlow,

Table 5. Diurnal changes in rates of protein synthesis (S), breakdown (B) and oxidation (O) on moving from the fasted to the fed state

\begin{tabular}{lcccl}
\hline & \multicolumn{3}{c}{ Rate fed: rate fasted } & \\
\cline { 2 - 4 } Protein intake $(\mathrm{g} / \mathrm{kg}$ per d) & $\mathrm{S}$ & $\mathrm{B}$ & $\mathrm{O}$ & Reference \\
\hline 1.5 & 1.27 & 1.07 & 1.77 & Hoffer et al. (1985) \\
not stated & 0.92 & 0.35 & 1.58 & Melville et al. (1989) \\
not stated & 1.03 & 0.57 & 1.45 & \\
0.36 & 1.21 & 0.40 & 2.75 & Young et al. (1983) \\
0.77 & 0.96 & 0.83 & 1.17 & Pacy et al. (1994) \\
1.59 & 1.03 & 0.78 & 1.50 & \\
2.07 & 1.17 & 0.64 & 1.73 & \\
1.0 & 1.20 & 0.44 & 1.69 & \\
0.1 & 1.15 & 0.80 & 2.15 & el Khoury et al. (1995) \\
0.7 & 0.87 & 0.77 & 0.77 & Gibson et al. (1996) \\
1.5 & 1.16 & 0.49 & 1.32 & \\
1.0 & 1.05 & 0.72 & - & Cayol et al. (1997) \\
2.5 & 1.10 & 0.72 & 2.03 & Forslund et al. (1998) \\
0.32 & 1.34 & 0.39 & 3.17 & \\
2.24 & 0.89 & 0.78 & 0.99 & Fereday et al. (1998) \\
\hline
\end{tabular}

*Single pool model. 
1995). This conclusion is supported by a study of Boirie et al. (1996), who fed a single meal containing labelled protein. Applying the non-steady-state equations, they showed that the response to the meal was an increase in synthesis with little change in breakdown.

It is clear, therefore, that the technical problems of determining synthesis and breakdown rates in vivo are by no means solved, and it may be necessary, as Hoerr (1991) suggested, to rethink what has become the standard doctrine, that the response to feeding protein is mainly by reduction in the rate of breakdown. However, as will be seen below, the partition of changes in synthesis and breakdown is not really of the first importance.

The arm or leg preparation. A third approach is based on studies of metabolism in the arm or leg, based on measurements of blood flow, arterio-venous differences in amino acid concentration and isotope exchange. This method was developed by Cheng et al. $(1985,1987)$. They showed that with feeding, compared with fasting, amino acid uptake was increased by $80 \%$, release was decreased by $11 \%$, and there was a positive $v$. negative balance. Gelfand $e t$ al. (1988) inserted a catheter into the hepatic vein so that they could make measurements in the viscera as well as the leg, and observed that the viscera accounted for $50 \%$ of whole-body turnover. Amino acid infusions stimulated leucine uptake by $40 \%$ in the splanchnic bed and reduced release by $50 \%$; the corresponding figures for the leg were $+82 \%$ and $-58 \%$ (see also Bennet et al. 1990a). In another experiment Svanberg et al. (1996) infused increasing levels of amino acids and found almost linear increases in synthesis and breakdown in the arm and leg preparations, without any change in the plasma concentration of insulin.

Amino acid infusions. The results of infusions of amino acids without insulin are summarized in Table 6 . On average they increased whole-body synthesis by $30 \%$. Breakdown was more variable; in one case it was decreased by $60 \%$, but in the four others it either fell a little or actually increased. There are, therefore, differences between the various kinds of study described above (long-term changes in protein intake, transitions from fasting to feeding, amino acid infusions and measurements on arm or leg) in their effects on the relative extent of changes in synthesis and breakdown. We cannot yet tell how far these differences in response represent real physiological differences, or whether they result from technical errors of measurement, some of which have already been mentioned.

The effects of insulin and other hormones. For a review of this subject, see the excellent review by Grizard et al. (1995). Of all the hormones that may influence protein metabolism in the short term, by far the most important is insulin. There is general agreement that infusion of insulin in both normal subjects and untreated diabetics reduces protein breakdown in the whole body and in muscle (Fukegawa et al. 1985; Tessari et al, 1988; McNurlan et al. 1994). There are four studies in which amino acids have been infused, first without and then with insulin (Bennet et al. 1990a,b; Pacy et al. 1991; Tessari et al. 1988). Insulin, on average, produced an $8 \%$ increase in synthesis and a $20 \%$ decrease in breakdown. Flakoll et al. (1989) produced evidence that amino acids augment the suppression of whole-body protein breakdown by insulin, and that 'there is a component of proteolysis that is highly dependent on plasma circulating amino acids'.

It is less clear whether insulin promotes synthesis, independently of amino acid supply. McNurlan et al. (1994) found that insulin had no effect on muscle protein synthesis in adult humans, although it has an important effect in rats, particularly young rats. Food stimulates secretion of insulin which, by inhibiting proteolysis, may lead to a fall in the plasma and intramuscular concentrations of some amino acids (Bennett et al. 1990b). It is difficult to disentangle these effects, and an experiment of Gibson et al. (1996) is of particular interest because it was done under conditions that were natural and physiological without infusions of insulin. Labelled leucine was infused for $9 \mathrm{~h}$; for the first $3 \mathrm{~h}$ the subjects were in the post-absorptive state, for the next $3 \mathrm{~h}$ on a 
low-protein diet, and for the final $3 \mathrm{~h}$ on a high-protein diet. On changing from fasting to the lowprotein diet plasma insulin levels increased 6-fold, but showed no further rise on transition to the high-protein diet. A highly significant correlation was found between changes in protein synthesis and plasma leucine concentration. The authors conclude that low protein intakes adequate in energy stimulate insulin secretion and inhibit protein breakdown; because of the reduced endogenous amino acid supply, tissue amino acids fall to a level at which synthesis is suppressed in spite of the presence of insulin. Although the prevailing view is that insulin's main action is the inhibition of proteolysis, it seems as if the effects of insulin and amino acids are additive. It is of some importance for the hypothesis put forward in the last section of this review to establish that amino acids act on both synthesis and breakdown.

Many experiments have shown that a variety of hormones can affect protein synthesis and breakdown (see Grizard et al. 1995). In human subjects Beaufrere et al. (1989) demonstrated catabolic effects of prednisone given in therapeutic doses. However, we are concerned here with physiological rather than pharmacological effects. In studies on protein feeding or amino acid infusions virtually no changes in plasma concentrations of hormones have been observed that could be related to alterations in protein synthesis or breakdown. No changes were found in glucagon (Pacy et al. 1988, 1994; Bennet et al. 1990a, b) except for one study by Bennet et al. (1989), in which infusions of amino acids increased the glucagon concentration by $40 \%$; nor were there any changes in insulin-like growth factor-1 (Bennet et al. 1990a,b; Pacy et al. 1994; Svanberg et al. 1996); cortisol (Bennet et al. 1990a, b); or total and free tri-iodothyronine (Pacy et al. 1994).

Amino acid concentrations. Many groups have measured the effects of protein intake, feeding/fasting or amino acid infusions on plasma amino acid concentrations. The results are difficult to interpret for several reasons: (1) when the protein intake is changed not all amino acid concentrations change in the same direction or to the same extent; (2) amino acid concentrations or their changes in plasma may not be representative of what is happening at the sites of protein synthesis and breakdown, thus in the study of Bennet et al. (1990b) insulin had opposite effects on the leucine concentrations in plasma and muscle, increasing it in plasma and decreasing it in muscle; (3) in most cases information about amino acid concentrations is only given in the initial state and at the ends of the periods during which protein kinetics are being measured. This makes it impossible to apply non-steady-state kinetics, which will undoubtedly be the next step in improving the accuracy of these measurements. An exception are the $24 \mathrm{~h}$ infusions of el Khoury, Young and their colleagues (el Khoury et al. 1994, 1995a,b, 1996) although even here only leucine concentration was measured.

Table 6. Effect of amino acid infusions without insulin on whole-body protein synthesis (S), breakdown (B) and oxidation (O). Values are ratios of synthesis, breakdown and oxidation during infusion to corresponding values in the basal state

\begin{tabular}{lcccl}
\hline \multirow{2}{*}{$\begin{array}{l}\text { Equivalent protein intake } \\
\text { (g/kg per d) }\end{array}$} & \multicolumn{2}{l}{ Rate during infusion : rate in basal state } & \\
\cline { 2 - 4 } & $\mathrm{S}$ & $\mathrm{B}$ & $\mathrm{O}$ & Reference \\
\hline 2.1 & 1.13 & 0.88 & 1.89 & Bennet et al. (1989) \\
2.0 & 1.40 & 0.85 & 2.00 & Pacy et al. (1988) \\
2.4 & 1.55 & 0.37 & 3.89 & Gelfand et al. (1988) \\
$1.5^{\star}$ & 1.21 & 1.19 & 2.56 & Goulet et al. (1993) \\
$2.5^{\star}$ & 1.31 & 1.18 & 5.84 & Goulet et al. (1993) \\
\hline
\end{tabular}

${ }^{*}$ In relation to infusion rate of $0.7 \mathrm{~g}$ protein $/ \mathrm{kg}$ per $\mathrm{d}$. 
It has been proposed that branched-chain amino acids, and leucine in particular, have a specific effect in stimulating protein synthesis or increasing sensitivity to insulin (Garlick \& Grant, 1988). This idea originally arose from experiments on muscle in vitro, but has not been confirmed in vivo (McNurlan et al. 1982; Papet et al. 1992). However, leucine does behave in a peculiar way, because in many studies plasma concentration falls in response to feeding protein, which does not seem to happen to the same extent with other amino acids. The explanation is probably that not only does leucine have a small free pool (the reason for its originally being adopted as a tracer), but it is also particularly abundant in tissue protein (7-8\%). Therefore leucine could easily become a limiting amino acid for protein synthesis.

I shall confine myself to one example of the problems of interpreting amino acid concentrations. The example is a truly remarkable experiment by Marchini et al. (1993), originally designed to give more precise information about human requirements for essential amino acids. Three separate diets were used, which all provided the same amount of total $\mathrm{N}$, equivalent to $0.9 \mathrm{~g}$ protein $/ \mathrm{kg}$ per $\mathrm{d}$, but different in their essential amino acid content. The first (FAO diet) contained $10 \%$, the second (MIT diet) $21 \%$ and the third (egg) $53 \%$ of total $\mathrm{N}$ as essential amino acids. Separate subjects, twenty in all, were assigned to each diet, and each subject had four infusions of $\left[{ }^{13} \mathrm{C}\right]$ leucine, covering fasted and fed states: a total of 80 infusions in all! All the subjects were on the adequate egg diet for their first infusions; the second infusion was after 1 week on the assigned diet, the third after 3 weeks and the fourth after 1 week of recovery on the egg diet. At the time of each infusion plasma concentrations were measured of the branched-chain amino acids and of four others, methionine, threonine, lysine and proline. The amount of information that emerged is enormous and I shall give here only a very abbreviated summary that I think brings out the main points. Only the results of the second infusion, after 1 week on the diet, are shown, because there was no further change after 3 weeks.

As regards the amino acids: on the FAO and MIT diets the fed-state levels of all three branched-chain amino acids were substantially lower than on the egg diet, and lower than the corresponding fasting concentrations, the same kind of fall stimulated by food that was found by Gibson et al. (1996) in the fasting state. These changes did not occur with the egg diet nor with any of the other four amino acids that were measured. The kinetic data (Table 7) are very interesting. As we move from a very low to a much higher essential amino acid intake, the fasting rates of synthesis, breakdown and oxidation all increased. At all three levels of protein intake, in the fasting state breakdown was greater than synthesis; oxidation depended on the previous dietary intake, in agreement with the hypothesis of Millward (1995), and was perhaps determined by the rate at which amino acids were liberated by proteolysis. In the fed state, synthesis was less than during fasting on the FAO and MIT diets although increasing with rising intake. Breakdown was very much reduced, and was strikingly constant on all three diets. We cannot tell whether this was because the total amino acid intake was the same on all three diets, or because all provoked the same insulin response. Finally, neither in the fed nor the fasted state was it possible to repress oxidation, so that at the low leucine intakes of the FAO and MIT diets the $24 \mathrm{~h}$ balances were negative. It may also be the case that amino acids destined for oxidation do not mix in a homogeneous pool with those recycled from breakdown to synthesis. Overall, these results agree well with the conclusions of Gibson et al. (1996) quoted earlier: 'Only when the dietary amino acid supply is sufficient to more than compensate for the marked inhibition of normal tissue breakdown are tissue amino acid levels sufficiently increased to stimulate protein synthesis'. It would seem that the prime mover in this rather complex series of events is the inhibition of proteolysis below the basal or fasting rate. This is the most complete analysis I know of, in which changes in amino acid concentration and protein kinetics are looked at together. 


\section{The coordination of protein synthesis and breakdown}

From the data discussed so far I think it is a widely accepted and reasonable hypothesis that amino acid supply, in cooperation with insulin, plays a major role in regulating rates of protein synthesis and breakdown in the body (for a review, see Kimball et al. 1994). How the effects of cell volume on synthesis and proteolysis in the liver, so elegantly demonstrated by the experiments of Haussinger and his group (Haussinger\& Lang, 1991; Stoll et al. 1992), can be reconciled with this hypothesis remains to be determined. Perhaps the liver is a special case. Be that as it may, there are many points in the synthetic pathway at which amino acids could exert control. A review by Pain \& Clemens (1980) gives an account of the mechanism of protein synthesis which, though it may be considered out of date by today's standards, provides a good starting-point for the non-specialist. Many years ago, Henshaw et al. (1971) and Millward et al. (1973) drew attention to changes in the efficiency of protein synthesis in tissues from animals on low-protein diets. Efficiency was measured by dividing the fractional rate of protein synthesis $\left(K_{\mathrm{s}}\right)$ by the RNA content of the tissue, and since about $85 \%$ of RNA is ribosomal, a change in efficiency without change in amount of RNA directed attention to the functional capacity of the ribosomes. Munro (1970) and others had already shown that amino acid deficiency caused disaggregation of ribosomes into oligosomes, which are incapable of translation, and suggested a major role for tryptophan as the amino acid most likely to be deficient. In perfused rat livers it was found that polysome disaggregation occurred when the perfusate contained no amino acids (Flaim et al. 1982a,b). Moreover, disaggregation could be produced very rapidly (Pain \& Clemens, 1980) and reversed equally quickly by amino acids or insulin. This, then, is one mechanism by which synthesis rates could be controlled by amino acids. There is also evidence that amino acids do not affect the charging of tRNA, but they do influence the phosphorylation/dephosphorylation state of the initiation factor eIF2 (Clemens, 1990; Pain 1994). For reviews of the subject of translational control, see Hershey (1991), Pain (1994), and most recently Hesketh et al. (1998).

The changes in amounts of the mRNA of the urea-cycle enzymes, and indeed of many other nutritionally important enzymes suggest transcriptional control. However, the stability of mRNA may be as important as their rates of production. There has been a great deal of work on

Table 7. Effect of three isonitrogenous diets with varying levels of essential amino acids on plasma leucine concentration and components of protein turnover*

(Values are the means of rates after 1 and 3 weeks on the diets)

\begin{tabular}{|c|c|c|c|}
\hline & FAO diet $\uparrow$ & MIT diet $\dagger$ & Egg diet $\uparrow$ \\
\hline Essential amino acids ( $\%$ total $\mathrm{N}$ in diet) & 10 & 21 & 53 \\
\hline \multicolumn{4}{|l|}{ Plasma leucine $(\mu \mathrm{mol} / \mathrm{I})$} \\
\hline $\begin{array}{l}\text { Fasted } \\
\text { Fed }\end{array}$ & $\begin{array}{r}111 \\
87\end{array}$ & $\begin{array}{r}138 \\
86\end{array}$ & $\begin{array}{l}143 \\
178\end{array}$ \\
\hline \multicolumn{4}{|l|}{ Synthesis ( $\mu \mathrm{mol} / \mathrm{kg}$ per $\mathrm{h})$} \\
\hline $\begin{array}{l}\text { Fasted } \\
\text { Fed }\end{array}$ & $\begin{array}{l}70 \\
69\end{array}$ & $\begin{array}{l}79 \\
75\end{array}$ & $\begin{array}{l}84 \\
88\end{array}$ \\
\hline \multicolumn{4}{|l|}{ Breakdown ( $\mu \mathrm{mol} / \mathrm{kg}$ per $\mathrm{h})$} \\
\hline $\begin{array}{l}\text { Fasted } \\
\text { Fed }\end{array}$ & $\begin{array}{l}78 \\
67\end{array}$ & $\begin{array}{l}89 \\
62\end{array}$ & $\begin{array}{l}98 \\
62\end{array}$ \\
\hline \multicolumn{4}{|l|}{ Oxidation ( $\mu \mathrm{mol} / \mathrm{kg}$ per $\mathrm{h})$} \\
\hline $\begin{array}{l}\text { Fasted } \\
\text { Fed }\end{array}$ & $\begin{array}{l}12 \\
11\end{array}$ & $\begin{array}{l}14 \\
18\end{array}$ & $\begin{array}{l}18 \\
33\end{array}$ \\
\hline
\end{tabular}

${ }^{\star}$ From Marchini et al. (1993). For further details of the experimental design, see p. 44.

$\dagger$ The three diets all provided the same amount of total nitrogen $(0.9 \mathrm{~g} / \mathrm{kg} / \mathrm{d})$. 
mRNA stability (e.g. Hentze, 1991; Ross, 1988, 1996), but it does not give any indication of stability being affected by amino acid concentration. However, in some cases there does seem to be a kind of self-regulating system, in which the stability of the messenger is controlled by its protein product (Cleveland, 1988; Kyrpides \& Ouzounis, 1993). The important point is that whereas molecular biology has identified a number of different points at which the synthesis of individual proteins is or may be controlled, there is no overall mechanism in sight that could be applied to the synthesis of body proteins in general.

When it comes to protein breakdown the most important contributor now appears to be the ATP-dependent ubiquitin system (Hershko, 1991). The incredible complexity of the enzymes involved, sub-units of the proteasome, has been described by Ciechanover \& Schwartz (1998). Specificity of breakdown appears to be conferred by the N-terminal amino acid structure of proteins exposed to proteolysis (Bachmair et al. 1986; Varshavsky, 1992, 1996). I have found no evidence of direct control of this process by amino acids, but progress in this direction is being made by the groups of Attaix and of Goldberg. They have shown in rats that in skeletal muscle atrophying from starvation, there is a correlated increase in activity of all the proteolytic pathways, including the ubiquitin-proteasome system, and a concurrent increase in the levels of the mRNA for components of these systems, including subunits of the proteasome complex (Medina et al. 1995; Taillandier et al. 1996; Attaix \& Taillandier, 1997). Similar effects were found in muscles of patients with head injury who were in negative $\mathrm{N}$ balance (Mansoor et al. 1996). Inhibition of protein breakdown with insulin and amino acids reduced mRNA levels for ubiquitin in skeletal muscle, but not in liver, jejunum or skin (Larbaud et al. 1996).

All this work gives some indication of possibilities for dietary control of synthesis and breakdown separately, but says nothing about how the two processes are coordinated so that in the steady state they cancel out. Years ago a simplistic explanation was proposed, based on kinetic considerations (Waterlow et al. 1978): if $\mathrm{M}$ is protein mass, $k_{\mathrm{s}}$ and $k_{\mathrm{d}}$ fractional rate constants of synthesis and degradation, and if $k_{\mathrm{s}}$ is taken as zero-order, $k_{\mathrm{d}}$ as first order, then at any level of $\mathrm{M}$ in the steady state, $k_{\mathrm{s}}=k_{\mathrm{d}} \mathrm{M}$, and any change in $k_{\mathrm{s}}$ will produce a new steady state. This system does not work, partly because it is unrealistic to suppose that such complicated processes as synthesis and breakdown can be described in terms of simple kinetic orders (Varshavsky, 1996), and partly because in relation to normal $\mathrm{N}$ balance large variations in $\mathrm{M}$ are not allowed (p. 33).

To a physiologist scanning the literature there seems to be no communication between specialists in the twin areas of protein synthesis and breakdown. Logically there has to be some connection and amino acids are the one common feature to which both systems are exposed; they are substrates of the one and products of the other. On this fact a tentative hypothesis can be built of how coordination is achieved, derived in part from a suggestion by Scornik (1984), who wrote: 'The regulatory role of amino acids is a particularly attractive subject of investigation. Its physiological significance is direct and immediate. The effects correct the cause: if amino acid pools are depleted, slower protein synthesis and faster breakdown tend to replenish them... some hormonal effects may be measured by changes in intracellular amino acid pools'. Scornik was thinking about maintaining the constancy of the free amino acid pool rather than protein balance, but he makes the two key points, that both synthesis and degradation are in principle self-limiting, and that amino acid concentration or supply affects the two processes in opposite directions.

Millward also has some interesting ideas on this question. He says that it is not possible to predict from first principles the most effective postprandial response of synthesis and degradation to minimize oxidation and maximize protein deposition: ${ }^{6} \ldots$. the results (of our studies) show that maximal inhibition of degradation and minimal stimulation of synthesis result in the most efficient protein utilization.... A lesser inhibition of degradation and a greater stimu- 
lation of synthesis result in less efficient protein utilization' (Fereday et al. 1998). Millward was not concerned with the coordination of synthesis and degradation, but rather with the most efficient combination of opposing processes to promote net protein synthesis. The basic problem, however, is the same.

From these ideas it is possible to generate a model as shown in Fig. 4, which I shall call the 'cross-over' model of coordination. The full lines represent the rate of protein synthesis (S) and breakdown (B). The dotted lines represent these rates in the presence of insulin. At some point the lines for S and B must cross, because they are going in opposite directions, and this is the point of balance. In cross-over regulation there is no need for a signal or a sensor of the signal. A similar scheme was proposed by Toates (1975) for balancing lipolysis and lipogenesis.

In this system one can visualize that in each tissue there might be a basal amino acid concentration at which 'appearance' and 'disposal' are equal. These basal concentrations need not be the same in all tissues. There may also be a difference in sensitivity in different tissues to changes in amino acid concentration, or to the action of insulin or other hormones. All such changes will alter the position of the curves and perhaps their slopes, but there will always be some point at which they cross. The position of the cross-over points may differ, but as each tissue will be in balance, the sum will be in balance. The same idea can be enlarged to show the equality between disposal, which is the sum of synthesis and oxidation, and appearance, which is the sum of proteolysis and intake. However, having discussed the problem of "external balance' in the earlier part of the review, I wish here to concentrate on the internal balance between the two components of protein turnover.

This scheme attempts to explain how balance could be achieved, as it were automatically, in the normal steady state. It is outside the scope of this review to consider non-steady states such as growth, injury or disease. All that can be said is that perhaps in such states there is an extra stimulus, outside the model, such as growth hormone and insulin-like growth factor-1 in the case of growth, glucocorticoids and cytokines in the case of injury, which is operating in such a powerful and sustained way that the balancing process cannot keep up.

\section{Conclusion}

The aim of this review is to identify points on which we are ignorant about a physiological process so familiar that it may easily be taken for granted. These points are as follows:

(1) What is the exact relationship between the flux of amino- $\mathrm{N}$ through the liver and the $\mathrm{NH}_{3}$ concentration at the site of entry to the urea cycle?

(2) What is the reason for changes in the activity of the urea-cycle enzymes with relatively modest alterations in protein intake?

(3) How are the changes in these enzymes coordinated?

(4) Why does it take so long for balance to be restored when $\mathrm{N}$ intake is changed?

(5) What is the exact relationship between $\mathrm{N}$ intake and urea production? The discrepancies that have been observed in man in vivo do not seem to fit with the kind of relationship predicted by measurements in vitro.

(6) Is urea salvage controlled, and if so, how?

(7) Does the model proposed for the co-ordination of protein synthesis and breakdown make sense? If not, what alternative can be suggested? 


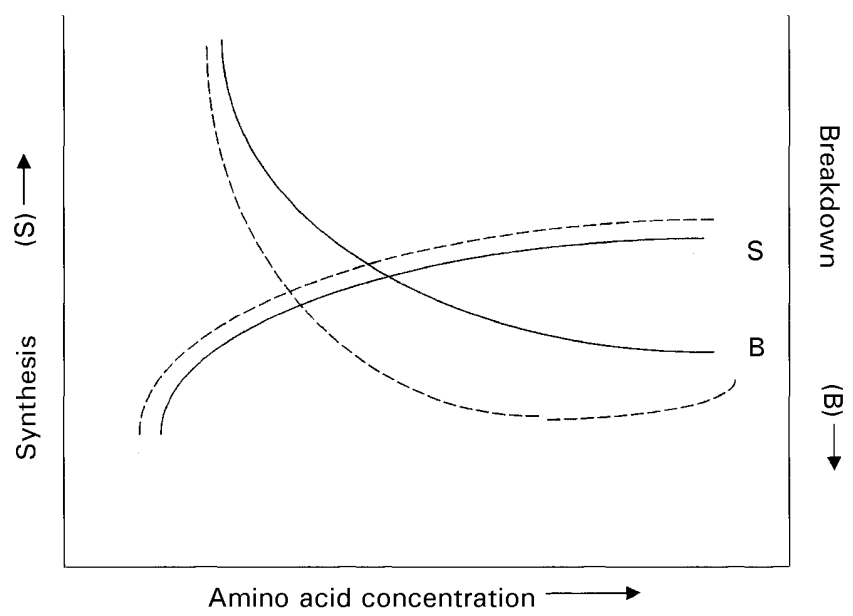

Fig. 4. Hypothetical model of effect of amino acid concentration on rates of protein synthesis (S) and breakdown $(B)$ and the modulating effect of insulin. Balance occurs at the point where the curves cross. Dotted lines slow the effects of insulin, which shifts the curves to the left, to produce the increase in sensitivity. Synthesis is only moderately sensitive to amino acid concentration, breakdown more so.

\section{Acknowledgement}

I am deeply indebted to D. J. Millward for constructive comments.

\section{References}

Adibi SA (1968) Influence of dietary deprivations on plasma concentrations of free amino acids in man. Journal of Applied Physiology 25, 52-57.

Adibi SA, Modesto TA, Morse EL \& Amin PF (1973) Amino acid levels in plasma, liver and skeletal muscle during protein deprivation. American Journal of Physiology 225, 408-414.

Ashkar ZM, Martial S, Isozaki T, Price SR \& Sands JF (1995) Urea transport in initial IMCD of rats fed a low-protein diet: functional properties and mRNA abundance. American Journal of Physiology 268, F1218-F1223.

Ashworth A \& Harrower ADB (1967) Protein requirements in tropical countries: nitrogen losses in sweat and their relation to nitrogen balance. British Journal of Nutrition 21, 833-843.

Atkinson DE \& Bourke E (1984) The role of ureagenesis in pH homeostasis. Trends in Biochemical Sciences 9, 297300 .

Attaix D \& Taillandier D (1997) The critical role of the ubiquitin-proteosome pathway in muscle wasting in comparison to lysosomal and $\mathrm{Ca}^{2+}$-dependent systems. Advances in Molecular and Cell Biology 27, 235-266.

Bachmair A, Finley D \& Varshavsky A (1986) In vivo half-life of a protein is a function of its amino-terminal residue. Science 234, 179-186.

Barber T, Vina JR, Vina J \& Cabo J (1985) Decreased urea synthesis in cafeteria-diet-induced obesity in the rat. Biochemical Journal 230, 675-681.

Beaufrere B, Horber FF, Schwenk WF, Marsh HM, Matthews D, Gerich JE \& Haymond MW (1989) Glucocorticoids increase leucine oxidation and impair leucine balance in humans. American Journal of Physiology 257, E712-E721.

Beliveau-Carey G, Cheung C-W, Cohen NS, Brusilow S \& Raijman L (1993) Regulation of urea and citrulline synthesis under physiological conditions. Biochemical Journal 292, 241-247.

Bennet WM, Connacher AA, Scrimgeour CM, Jung RT \& Rennie MJ (1990a) Euglycemic hyper insulinemia augments amino acid uptake by human leg tissues during hyperaminoacidemia. American Journal of Physiology 259, E185E194.

Bennet WM, Connacher AA, Scrimgeour CM, Smith KM \& Rennie MJ (1989) Increase in anterior tibialis muscle protein synthesis in healthy man during mixed amino acid infusions: studies of incorporation of $\left[1-{ }^{13} \mathrm{C}\right] l$ leucine. Clinical Science 76, 447-454.

Bennet WM, Connacher AA, Smith K, Jung RT \& Rennie MJ (1990b) Inability to stimulate skeletal muscle or whole body protein synthesis in type I (insulin-dependent) diabetic patients by insulin-plus-glucose during amino acid infusion: studies of incorporation and turnover of L- $\left[1-{ }^{13} \mathrm{C}\right]$ leucine. Diabetologia 33, 43-51. 
Bergström J, Fürst P, Noree L-O \& Vinnars E (1974) Intracellular free amino acid concentration in human muscle tissue. Journal of Applied Physiology 36, 693-697.

Boirie Y, Gachon P, Comy S, Fauquant J, Maubois J-L \& Beaufrere B (1996) Acute post-prandial changes in leucine metabolism as assessed with an intrinsically labeled milk protein. American Journal of Physiology 271, E1083E1091.

Brown RJ, Duda JD, Korkes S \& Handler P (1957) A colorimetric micromethod for determination of ammonia: the ammonia content of rat tissues and human plasma. Archives of Biochemistry and Biophysics 66, 301-309.

Bundy R, Persaud C \& Jackson AA (1993) Measurement of urea kinetics with a single dose of $\left[{ }^{15} \mathrm{~N}^{15} \mathrm{~N}\right]$-urea in freeliving vegetarians on their habitual diet. International Journal of Food Science and Nutrition 44, 253-259.

Carraro F, Kimbrough TD \& Wolfe RR (1993) Urea kinetics in humans at two levels of exercise intensity. Journal of Applied Physiology 75, 1180-1185.

Cayol M, Boirie Y, Rambourdin F, Prugnaud J, Gachon P, Beaufrere B \& Obled C (1997) Influence of protein intake on whole body and splanchnic leucine kinetics in humans. American Journal of Physiology 272, E584-E591.

Chan HV (1968) Adaptation of urinary nitrogen excretion in infants to changes in protein intake. British Journal of Nutrition 22, 315-323.

Chee PY \& Swick RW (1976) Effect of dietary protein and tryptophan on the turnover of liver ornithine aminotransferase. Journal of Biological Chemistry 251, 1029-1034.

Cheng KN, Dwozak F, Ford GC, Rennie MJ \& Halliday D (1985) Direct determination of leucine metabolism and protein breakdown in humans using $\mathrm{L}-\left[1^{13} \mathrm{C},{ }^{15} \mathrm{~N}\right]$ leucine and the forearm model. European Journal of Clinical Investigation 15, 349-354.

Cheng KN, Pacy PJ, Dworzak F, Ford GC \& Halliday D (1987) Influence of fasting on leucine and muscle protein metabolism across the human forearm determined using $\mathrm{L}-\left[1-{ }^{13} \mathrm{C},{ }^{15} \mathrm{~N}\right]$ leucine as the tracer. Clinical Science 73, $241-246$.

Cheung CW, Cohen NS \& Raijman L (1989) Channeling of urea cycle intermediates in situ in permeabilized hepatocytes. Journal of Biological Chemistry 264, 4038-4044.

Cheung CW \& Raijman L (1980) The regulation of carbamoyl phosphate synthetase (ammonia) in rat liver mitochondria. Journal of Biological Chemistry 255, 5051-5057.

Child SC, Soares MJ, Reid M, Persaud C, Forrester T \& Jackson AA (1997) Urea kinetics varies in Jamaican women and men in relation to adiposity, lean body mass and protein intake. European Journal of Clinical Nutrition 51, 107115 .

Ciechanover A \& Schwartz AL (1998) The ubiquitin-proteasome pathway: the complexity and myriad functions of proteins death. Proceedings of the National Academy of Sciences, USA 95, 2727-2730.

Clemens MJ (1990) Does protein phosphorylation play a role in translational control by eukaryotic aminoacyl-tRNA synthetases? Trends in Biochemical Sciences 15, 172-175.

Cleveland DW (1988) Autoregulated instability of tubular mRNAs. Trends in Biochemical Sciences 13, $339-343$.

Clugston GA \& Garlick PJ (1982) The response of protein and energy metabolism to food intake in lean and obese man. Human Nutrition: Clinical Nutrition 36C, 57-70.

Cohen NS, Cheung C-W \& Raijman L (1987) Channelling of extra mitochondrial ornithine to matrix ornithine transcarbamylase. Journal of Biological Chemistry 262, 203-208.

Cohen NS, Kian F, Kian SS, Cheung C-W \& Raijman L (1985) The apparent $\mathrm{K}_{\mathrm{m}}$ of ammonia for carbamoyl phosphate synthetase (ammonia) in situ. Biochemical Journal 229, 205-211.

Cooper AJL, Nieves E, Coleman AE, Filc-De Ricco S \& Gelbard AS (1987) Short-term metabolic fate of $\left[{ }^{13} \mathrm{~N}\right]$ ammonia in rat liver in vivo. Journal of Biological Chemistry 262, 1073-1080.

Cooper AJL, Nieves E, Rosenspire KC, Filc-De Ricco S, Gelbard AS \& Brusilow SW (1988) Short-term metabolic fate of ${ }^{13} \mathrm{~N}$-labeled glutamate, alanine and glutamine (amide) in rat liver. Journal of Biological Chemistry 263, 1226812273.

Danielsen M \& Jackson AA (1992) Limits of adaptation to a diet low in protein in normal man: urea kinetics. Clinical Science 83, 103-108.

Das TK \& Waterlow JC (1974) The rate of adaptation of urea cycle enzymes, aminotransferases and glutamate dehydrogenase to changes in dietary protein intake. British Journal of Nutrition 32, 353-373.

de Groot CJ, van Zonneveld AJ, Moores PG, Zonneveld D, van den Dool A, van den Bogaert AJW, Lammers WH, Moorman AFM \& Charles R (1984) Regulation of mRNA levels of rat liver carbamoyl phosphate synthetase by glucocorticoids and cyclic AMP as estimated with a specific cDNA. Biochemical and Biophysical Research Communications 124, $882-888$

Dodgson SJ \& Forster RE (1986). Carbonic anhydrase: inhibition results in decreased urea production by hepatocytes. Journal of Applied Physiology 60, 646-652.

Duda GD \& Handler P (1958) Kinetics of ammonia metabolism in vivo. Journal of Biological Chemistry 232, 303314.

el Khoury AE, Ajami AM, Fukagawa NK, Chapman E \& Young VR (1996) Diurnal pattern of the interrelationships among leucine oxidation, urea production and hydrolysis in humans. American Journal of Physiology 271, E563E573.

el Khoury AE, Fukagawa NK, Sanchez M, Tsay RH, Gleason AE, Chapman TE \& Young VR (1994) Validation of the tracer-balance concept with reference to leucine: $24-\mathrm{h}$ intravenous tracer studies with L- $\left[1-{ }^{13} 15 \mathrm{~N}-{ }^{15} \mathrm{~N}\right] \mathrm{urea}$. American Journal of Clinical Nutrition 59, 1000-1011. 
el Khoury AE, Sanchez M, Fukagawa NK, Gleason RE, Tsay RH \& Young VR (1995b) The 24-h kinetics of leucine oxidation in healthy adults receiving a generous leucine intake via three discrete meals. American Journal of Clinical Nutrition 62, 579-590.

el Khoury AE, Sanchez M, Fukagawa NK \& Young VR (1995a) Whole body protein synthesis in healthy adult humans: ${ }^{13} \mathrm{CO}_{2}$ technique vs. plasma precursor approach. American Journal of Physiology 268, E174-E184.

Felipe V, Minana M-D \& Grisolia S (1991) Control of urea synthesis and ammonia utilization in protein deprivation and refeeding. Archives of Biochemistry and Biophysics 285, 351-356.

Fereday A, Gibson NR, Cox M, Pacy P \& Millward DJ (1998) Variation in the apparent sensitivity of the insulinmediated inhibition of proteolysis to amino acid supply determines the efficiency of protein utilization. Clinical Science 95, 725-733.

Fern EB \& Garlick PJ (1974) The specific radioactivity of the tissue free amino acid pool as a basis for measuring the rate of protein synthesis of the rat in vivo. Biochemical Journal 142, 413-419.

Flaim KE, Liao WSL, Peavy DE, Taylor JM \& Jefferson LS (1982b) The role of amino acids in the regulation of protein synthesis in rat liver. II. Effects of amino acid deficiency on peptide-chain initiation, polysome aggregation and distribution of mRNA. Journal of Biological Chemistry 257, 2939-2946.

Flaim KE, Peavy DE, Everson WV \& Jefferson LS (1982a) The role of amino acids in the regulation of protein synthesis in rat liver. I. Reduction in rates of synthesis resulting from amino acid deprivation and recovery during flow-through perfusion. Journal of Biological Chemistry 257, 2932-2938.

Flakoll PJ, Kulayat M, Frexes-Steed M, Hourani H, Brown LL, Hill JO \& Abumrad NN (1989) Amino acids augment insulin's suppression of whole body proteolysis. American Journal of Physiology 257, E839-E847.

Folin O (1905) Laws governing the chemical composition of urine. American Journal of Physiology 13, 66-115.

Forslund AM, Hambraeus L, Olsson RM, el Khoury AE, Yu Y-M \& Young VR (1998) The 24h whole body leucine and urea kinetics at normal and high protein intakes with exercise in healthy adults. American Journal of Physiology $\mathbf{2 7 5}$, E310-E320.

Fukagawa NK, Minaker KL, Rowe JW, Goodman MH, Matthews DE, Bier DM \& Young VR (1985) Insulin-mediated reduction of whole body protein breakdown. Dose response effects on leucine metabolism in post-absorptive men. Journal of Clinical Investigation 76, 2306-2311.

Garlick PJ \& Grant I (1988) Amino acid infusion increases the sensitivity of muscle protein synthesis to insulin. Biochemical Journal 254, 579-584.

Garlick PJ, McNurlan MA \& Ballmer PE (1991) Influence of dietary protein intake on whole-body protein turnover in humans. Diabetes Care 14, 1189-1198.

Geissler A, Kanamori K \& Ross BD (1992) Real-time study of the urea cycle using ${ }^{15} \mathrm{~N}$ n.m.r. in the isolated perfused rat liver. Biochemical Journal 287, 813-820.

Gelfand RA, Glickman MG, Castellino P, Louard RJ \& De Fronzo RA (1988) Measurement of L- $\left[1-{ }^{14}\right.$ C $]$ leucine kinetics in splanchnic and leg tissues in humans. Diabetes 37, 1365-1372.

Gibson NR, Fereday A, Cox M, Halliday D, Pacy PJ \& Millward DJ (1996) Influences of dietary energy and protein on leucine kinetics during feeding in healthy adults. American Journal of Physiology 270, E282-E291.

Goulet O, DePotter S, Salas J, Robert J-J, Rongier M, Ben Hariz M, Koziet J, Desjeux J-F, Ricour C \& Darmain D (1993) Leucine metabolism at graded amino acid intakes in children receiving parenteral nutrition. American Journal of Physiology 265, E540-E546.

Grizard J, Dardevet D, Papet I, Mosoni L, Mirand PP, Attaix D, Tauveron I, Bonin D \& Arnal M (1995) Nutrient regulation of skeletal muscle protein in animals. The involvement of hormones and substrates. Nutrition Research Reviews 9, 67-92.

Halperin ML, Chen CB, Cheema-Dhadli S, West ML \& Jungas RL (1986) Is urea formation regulated primarily by acid-base balance in vivo? American Journal of Physiology 250, F605-F612.

Harper AE (1983) Some recent developments in the study of amino acid metabolism. Proceedings of the Nutrition Society 42, 437-449.

Harris RA, Paxton S, Powell SM, Goodwin GW, Kuntz MJ \& Han AC (1986) Regulation of branched-chain 2-oxoacid dehydrogenase complex by covalent modification. Advances in Enzyme Regulation 25, 219-237.

Haussinger D (1983) Hepatocyte heterogeneity in glutamine and ammonia metabolism and the role of an intracellular glutamine cycle during ureogenesis in perfused rat liver. European Journal of Biochemistry 133, 269-275.

Haussinger DD, Gerok W \& Sies H (1984) Hepatic role in pH regulation: role of the intercellular glutamine cycle. Trends in Biochemical Sciences 9, 300-302.

Haussinger D \& Lang F (1991) Cell volume in the regulation of hepatic function: a mechanism for metabolic control. Biochimica et Biophysica Acta 1071, 331-350.

Hems R, Ross DB, Berry MN \& Krebs HA (1966) Gluconeogenesis in perfused rat liver. Biochemical Journal 101, $284-292$.

Henshaw EO, Hirsch CA, Morton BE \& Hiatt HH (1971) Control of protein synthesis in mammalian tissue through changes in ribosome activity. Journal of Biological Chemistry 246, 436-446.

Hentze MW (1991) Determinants and regulation of cytoplasmic mRNA stability in eukaryotic cells. Biochimica et Biophysica Acta 1090, 281-292.

Hershey JWB (1991) Translational control in mammalian cells. Annual Reviews of Biochemistry 60, 717-755.

Hershko A (1991) The ubiquitin pathway of protein degradation and proteolysis of ubiquitin-protein conjugates. Biochemical Society Transactions 19, 726-729. 
Hesketh JE (1996) Sorting messenger RNAs in the cytoplasm: mRNA localization and the cytoskeleton. Experimental Cell Research 225, 219-236.

Hesketh JE, Vasconcelos MH \& Bermano G (1998) Regulatory signals in messenger RNA: determinants of nutrient-gene interaction and metabolic compartmentation. British Journal of Nutrition 80, 307-321.

Hibbert JM, Forrester T \& Jackson AA (1992) Urea kinetics: comparison of oral and intravenous dose regimes. European Journal of Clinical Nutrition 46, 405-409.

Hibbert JM \& Jackson AA (1991) Variations in measures of urea kinetics over four years in a single adult. European Journal of Nutrition 45, 347-352.

Hibbert JM, Jackson AA \& Persaud C (1995) Urea kinetics: effect of severely restricted dietary intakes on urea hydrolysis. Clinical Nutrition 14, 242-248.

Hoerr RA, Matthews DE, Bier DM \& Young VR (1991) Leucine kinetics from $\left[{ }^{2} \mathrm{H}_{3}\right]$-and $\left[{ }^{13} \mathrm{C}\right]$ leucine infused simultaneously by gut and vein. American Journal of Physiology 260, E111-E117.

Hoerr RA, Matthews DE, Bier DM \& Young VR (1993) Effects of protein restriction and acute refeeding on leucine and lysine kinetics in young men. American Journal of Physiology 264, E567-E575.

Hoffer LJ, Yang RD, Matthews DE, Bistrian BR, Bier DM \& Young VR (1985) Effects of meal consumption on whole body leucine and alanine kinetics in young men. British Journal of Nutrition 53, 31-38.

Jackson AA (1992) Critique of protein-energy interactions in vivo: urea kinetics. In Protein-Energy Interactions, pp. 63 79. [NS Scrimshaw and B Schurch, editors]. Lausanne, Switzerland: Nestlé Foundation.

Jackson AA (1998) Salvage of urea-nitrogen in the large bowel; functional significance in metabolic control and adaptation. Biochemical Society Transactions 26, 231-236.

Jackson AA, Picou D \& Landman J (1984) The non-invasive measurement of urea kinetics in man by a constant infusion of ${ }^{15} \mathrm{~N}^{15} \mathrm{~N}$-urea. Human Nutrition: Clinical Nutrition 38C, 339-354.

Jackson MJ, Beaudet AL \& O’Brien WE (1986) Mammalian urea cycle enzymes. Annual Review of Genetics 20, 431 464.

James WPT \& Hay AM (1968) Albumin metabolism: effect of the nutritional state and the dietary protein intake. Journal of Clinical Investigation 47, 1958-1972.

Kenney FT (1970) Hormonal regulation of synthesis of liver enzymes. In Mammalian Protein Metabolism, vol. IV, pp. 131-177 [HN Munro, editor]. New York: Academic Press.

Kies C \& Fox HM (1978) Urea as a dietary supplement for humans. Advances in Experimental Medicine and Biology 105, $103-118$

Kimball SR, Vary TC \& Jefferson LS (1994) Regulation of protein synthesis by insulin. Annual Review of Physiology 56, $321-348$.

Knepper MA \& Star RA (1990) The vasopressin-regulated urea transporter in renal inner medullary collecting duct. American Journal of Physiology 259, F393-F401.

Krebs HA (1972) Some aspects of the regulation of fuel supply in omnivorous animals. Advances in Enzyme Regulation 10, 397-420.

Krebs HA (1973) The discovery of the ornithine cycle of urea synthesis. Biochemical Education 1, 19-23.

Krebs HA (1976) The role of chemical equilibria in organ function. Advances in Enzyme Regulation 14, 449-472.

Krebs HA, Hems R \& Lund P (1973) Some regulatory mechanisms in the synthesis of urea in the mammalian liver. Advances in Enzyme Regulation 11, 361-377.

Krebs HA \& Henseleit K (1932) Untersuchusen über die Harnstoffebildung im Tierkörper (Investigations of urea metabolism in the animal body). Hoppe-Seyler's Zeitschrift für Physiologische Chemie 210, 33-66.

Krebs HA, Lund P \& Stubbs M (1976) Interrelations betweeen gluconeogenesis and urea synthesis. In Gluconeogenesis, pp. 269-291 [RW Hanson and MA Mehiman, editors]. London: John Wiley.

Kyrpides NC \& Duzounis CA (1993) Mechanisms of specificity in mRNA degradation: autoregulation and cognate interactions. Journal of Theoretical Biology 163, 373-392.

Langran M, Moran BJ, Murphy JL \& Jackson AA (1992) Adaptation to a diet low in protein: effect of complex carbohydrate upon urea kinetics in normal man. Clinical Science 82, 191-198.

Larbaud D, Debras E, Taillandier D, Samuels SE, Tempari S, Champedron C, Grizard J \& Attaix D (1996) Triglycemic hyperinsulinemia and hyperaminoacidemia decrease skeletal muscle ubiquitin mRNA in goats. American Journal of Physiology 271, E402-E413.

Lobley GE, Connell A, Lomax MA, Brown DS, Milne E, Calder AG \& Farningham DAM (1995) Hepatic detoxification of ammonia in the ovine liver: possible consequences for ammonia catabolism. British Journal of Nutrition 73, 667-685.

Lobley GE, Weijs PJM, Connell A, Calder AG, Brown DS \& Milne E (1996) The fate of absorbed and exogenous ammonia as influenced by forage or forage-concentrate diets in growing sheep. British Journal of Nutrition 76, $231-$ 248.

Lund P \& Wiggins D (1984) Is N-acetylglutamate a short-term regulator of urea synthesis? Biochemical Journal 218, 991-994.

McClelland I-SM, Persaud C \& Jackson AA (1997) Urea kinetics in healthy women during normal pregnancy. British Journal of Nutrition 77, $165-181$.

McGivan JD, Bradford NM \& Chappell JB (1974) Adaptive changes in the capacity of systems used for the synthesis of citrulline in rat liver mitochondria in response to high- and low-protein diets. Biochemical Journal 142, $359-364$. 
McGivan JD, Bradford NM \& Mendes-Mourao J (1976) The regulation of carbamoyl phosphate synthase activity in rat liver. Biochemical Journal 154, 415-421.

McNurlan MA, Essen P, Thorell A, Calder AG, Anderson SE, Ljungquist O, Sandgren A, Grant I, Tjader I, Ballmer PE, Wernerman J \& Garlick PJ (1994) Response of protein synthesis in human skeletal muscle to insulin: an investigation with $\mathrm{L}-\left[{ }^{2} \mathrm{H}_{5}\right]$ phenylalanine. American Journal of Physiology 267, E102-E108.

McNurlan MA, Fern EB \& Garlick PJ (1982) Failure of leucine to stimulate protein synthesis in vivo. Biochemical Journal 204, 831-838.

Mansoor O, Beaufrere B, Boirie Y, Ralliere C, Taillardier D, Aurousseau E, Schoeffler P, Amal M \& Attaix D (1996) Increased mRNA levels for components of the lysosomes, $\mathrm{Ca}^{2+}$-activated, and ATP-ubiquitin-dependent proteolytic pathways in skeletal muscle from head trauma patients. Proceedings of the National Academy of Sciences, USA 93, $2714-2718$.

Marchini JS, Cortiella J, Hiramatsu T, Chapman TE \& Young VR (1993) Requirements for indispensable amino acids in adult humans: longer-term kinetic study with support for the adequacy of the Massachusetts Institute of Technology amino acid requirement pattern. American Journal of Clinical Nutrition 58, 670-683.

Mariani A, Spadoni MA \& Tomassi G (1963) Effect of protein-depletion on amino-acid activating enzymes of rat liver. Nature (London) 199, 378-379.

Martin CJ \& Robison R (1922) The minimum nitrogen expenditure of man and the biological value of various proteins for human nutrition. Biochemical Journal 16, 407-420.

Matthews DE, Schwarz HP, Yang RD, Motil KJ \& Young VR (1982) Relationship between plasma leucine and alphaketo-isocaproate during a $\mathrm{L}\left[1-{ }^{13} \mathrm{C}\right]$ leucine infusion in man: a method for measuring human intracellular enrichment. Metabolism 31, 1105-1112.

Matthews DE, Marano MA \& Campbell RG (1993) Splanchnic bed utilization of leucine and phenylalanine in humans. American Journal of Physiology 264, E109-E118.

Meakins TS \& Jackson AA (1995)Diurnal cycling in urea nitrogen hydrolysis. Proceedings of the Nutrition Society 54, 137A.

Meakins TS \& Jackson AA (1996) Salvage of exogenous urea nitrogen enhances nitrogen balance in normal men consuming marginally inadequate protein diet. Clinical Science 90, 215-225.

Medina R, Wing SS \& Goldberg AL (1995) Increase in levels of polyubiquitin and proteasome mRNA in skeletal muscle during starvation and denervation atrophy. Biochemical Journal 307, 631-637.

Meijer AJ, Lamers WH \& Chamuleau RAFM (1990) Nitrogen metabolism and ornithine cycle function. Physiological Reviews 70, 701-748.

Meijer AJ, Lof C, Ramos IC \& Verhoeven AJ (1985) Control of ureagenesis. European Journal of Biochemistry 148, $189-196$.

Melville S, McNurlan MA, McHardy KC, Broom J, Milne E, Calder AG \& Garlick PJ (1989) The role of degradation in the acute control of protein balance in adult man: failure of feeding to stimulate protein synthesis as assessed by L[1$\left.{ }^{13} \mathrm{C}\right]$ leucine infusion. Metabolism 38, 248-255.

Millward DJ (1995) A protein-stat mechanism for regulation of the lean body mass. Nutrition Research Reviews 8, $93-120$. Millward DJ, Garlick PJ, James WPT, Nnanyelugo DO \& Ryatt JS (1973) Relationship between protein synthesis and RNA content in skeletal muscle. Nature (London) 241, 204-205.

Mori M, Miura S, Tatibana M \& Cohen PP (1981) Cell-free translation of carbamyl phosphate synthetase -1 and ornithine transcarbamylase messenger RNAs of rat liver. Journal of Biological Chemistry 256, 4127-4132.

Morris SM (1992) Regulation of enzymes of urea and arginine synthesis. Annual Reviews of Nutrition 12, $81-101$.

Morris SM, Moncman CL, Rand KD, Dizikes GJ, Cederbaum SD \& O'Brien WE (1987) Regulation of mRNA levels for five urea cycle enzymes in rat liver by diet, cyclic AMP and glucocorticoids. Archives of Biochemistry and Biophysics 256, 343-353.

Motil KJ, Matthews DE, Bier DM, Burke JF, Munro HN \& Young VR (1981) Whole body leucine and lysine metabolism: response to dietary protein intake in young men. American Journal of Physiology 240, E712-E721.

Motil KJ, Opekun AR, Montandon CM, Berthold HK, Davis TA, Klein P \& Reeds PJ (1994) Leucine oxidation changes rapidly after dietary protein intake is altered in adult women, but lysine flux is unchanged, as is lysine incorporation into VLDL-apolipoprotein B-100. Journal of Nutrition 124, 41-51.

Munro HN (1970) Free amino acid pools In Mammalian Protein Metabolism vol. IV, pp. 299-386 [HN Munro, editor]. New York: Academic Press.

Nicoletti M, Guerri C \& Grisolia S (1977) Turnover of carbamyl-phosphate synthase, of other mitochondrial enzymes and of rat tissues. European Journal of Biochemistry 75, 583-592.

O'Keefe SJD, Sender PM \& James WPT (1974) "Catabolic" loss of body nitrogen in response to surgery. Lancet ii, $1035-1038$.

Pacy PJ, Garrow JS, Ford GC, Merritt H \& Halliday D (1988) Influence of amino acid administration on whole body leucine kinetics and resting metabolic rate in postabsorptive normal subjects. Clinical Science 75, $225-231$.

Pacy PJ, Price GM, Halliday D, Quevedo M \& Millward DJ (1994) Nitrogen homoeostasis in man: the diurnal responses of protein synthesis and degradation and amino acid oxidation to diets with increasing protein intakes. Clinical Science 86, $103-118$.

Pacy PJ, Thompson GN \& Halliday D (1991) Measurement of whole body protein turnover in insulin-dependent (type I) diabetic patients during insulin withdrawal and infusion: comparison of $\left[{ }^{13} \mathrm{C}\right]$ leucine and $\left[{ }^{2} \mathrm{H}_{5}\right]$ phenylalanine methodologies. Clinical Science 80, 345-352.

Pain VM (1994) Translational control during amino acid starvation. Biochimie 76, 718-728. 
Pain VM \& Clemens MJ (1980) Protein synthesis in mammalian systems. In Comprehensive Biochemistry. Protein Metabolism, vol. 19B, pp. 1-76 [A Neuberger and L M Van Deenen, editors]. Amsterdam, The Netherlands: Elsevier.

Papet I, Glomot F, Grizard J \& Arnal M (1992) Leucine excess under conditions of low or compensated aminoacidemia does not change skeletal muscle and whole body protein synthesis in suckling lambs during the post-prandial period. Journal of Nutrition 122, 2307-2315.

Patterson BW, Carraro F, Klein S \& Wolfe RR (1995) Quantification of incorporation of $\left[{ }^{15} \mathrm{~N}\right]$ ammonia into plasma amino acids and urea. American Journal of Physiology 269, E508-E515.

Picou D \& Phillips M (1972) Urea metabolism in malnourished and recovered children receiving a high or low protein diet. American Journal of Clinical Nutrition 25, 1261-1266.

Price GM, Halliday D, Pacy PJ, Quevedo MR \& Millward DJ (1994) Nitrogen homoeostasis in man: influence of protein intake on the amplitude of diurnal cycling of body nitrogen. Clinical Science 86, 91-102.

Quevedo MR, Price GM, Halliday D, Pacy PJ \& Millward DJ (1994) Nitrogen homoeostasis in man: diurnal changes in nitrogen excretion, leucine oxidation and whole body leucine kinetics during a reduction from a high to a moderate protein intake. Clinical Science 86, 185-193.

Rafoth RJ \& Onstad GR (1975) Urea synthesis after oral protein ingestion in man. Journal of Clinical Investigation 56, $1170-1174$

Rand WR, Scrimshaw NS \& Young VR (1979) An analysis of temporal patterns in urinary nitrogen excretion of young adults receiving constant diets at low nitrogen intakes for two weeks. American Journal of Clinical Nutrition 32, $1408-1414$.

Rand WR, Young VR \& Scrimshaw NS (1976) Change of urinary nitrogen excretion in response to low protein diets in adults. American Journal of Clinical Nutrition 29, 639-644.

Randle PJ (1984) Regulatory devices in metabolism and medicine. Journal of the Royal College of Physicians, London 18, 211-218.

Reeds PJ, Hachey DL, Patterson PW, Motil KJ \& Klein PD (1992) LDL apoprotein B-100, a potential indicator of the isotopic labeling of the hepatic protein synthetic pool in humans: studies with multiple stable isotopically labelled amino acids. Journal of Nutrition 122, 457-466.

Rennie MJ, Edwards RHT, Halliday D, Matthews DE, Wolman SL \& Millward DJ (1982) Muscle protein synthesis measured by stable isotope techniques in man: the effects of feeding and fasting. Clinical Science 63, 519-523.

Richards P (1972) Nutritional potential of nitrogen recycling in man. American Journal of Clinical Nutrition 25, 615-625.

Rogers QR (1976) The nutritional and metabolic effects of amino acid imbalances. In Protein Metabolism and Nutrition, pp. 279-301 [DJA Cole, editor]. London: Butterworth.

Ross J (1988) Messenger RNA turnover in eukaryotic cells. Molecular Biology and Medicine 5, 1-14.

Ross J (1996) Control of messenger RNA stability in higher eukaryotes. Trends in Genetics 12, $171-175$.

Saheki T, Tsuda M, Takada S, Kusumi K \& Katsumuma T (1980) Role of argininosuccinate synthetase in the regulation of urea synthesis in the rat and argininosuccinate synthetase-associated metabolic disorder in man. Advances in Enzyme Regulation 18, 221-238.

Sarraseca A, Milne E, Metcalf MJ \& Lobley GE (1998) Urea recycling in sheep: effect of intake. British Journal of Nutrition 79, 79-88.

Schimke RT (1962a) Studies in factors affecting the levels of urea cycle enzymes in rat liver. Journal of Biological Chemistry 238, 1012-1018.

Schimke RT (1962b) Differential effects of fasting and protein-free diets on levels of urea-cycle enzymes in rat liver. Journal of Biological Chemistry 237, 1921-1924.

Schimke RT (1964) The importance of both synthesis and degradation in the control of arginase levels in rat liver. Journal of Biological Chemistry 239, 3808-3817.

Schimke RT (1970) Regulation of protein degradation in mammalian tissues. In Mammalian Protein Metabolism, vol.I, pp.177-228 [HN Munro, editor]. New York: Academic Press.

Scornik OA (1984) Role of protein degradation in the regulation of cellular protein content and amino acid pools. Federation Proceedings 43, $1283-1288$.

Shigesada K, Aoyagi K \& Tatibana M (1978) Role of acetylglutamate in ureotelism. European Journal of Biochemistry 85, 385-391.

Shigesada K \& Tatibana M (1978) N-acetyl glutamate synthetase from rat-liver mitochondria. Partial purification and catalytic properties. European Journal of Biochemistry 84, 285-291.

Shipley RA \& Clark RE (1972) Tracer Methods for in vivo Kinetics. New York: Academic Press.

Smith CP, Lee W-S, Martial S, Knepper MA, Yon G, Sands JM \& Heddiger MA (1995) Cloning and regulation of expression of the rat kidney urea transporter (rUT2). Journal of Clinical Investigation 96, 1556-1563.

Smith CP, Shayakul C, Knepper MA \& Heddiger MA (1996) Molecular physiology of urea transport. Journal of Physiology 493, 25-35.

Snyderman SE, Holt E, Dancis J, Roitman E, Boyer A \& Balis EM (1962) “Unessential” nitrogen: a limiting factor for human growth. Journal of Nutrition 78, 57-72.

Speth J (1989) Early hominid hunting and scavenging: the role of meat as an energy source. Journal of Human Evolution 18, 329-343.

Steffee WP, Anderson CF \& Young VR (1981) An evaluation of the diurnal rhythm of urea excretion in healthy young adults. Journal of Enteral and Parenteral Nutrition 5, 378-384.

Stephen JML \& Waterlow JC (1968) Effect of malnutrition on activity of two enzymes concerned with amino acid metabolism in human liver. Lancet 1, 118-119. 
Stewart PM \& Walser M (1980) Short-term regulation of ureagenesis. Journal of Biological Chemistry 255, 5270-5280. Stoll B, Gerok W, Lang F \& Haussinger D (1992) Liver cell volume and protein synthesis. Biochemical Journal 287, $217-222$.

Svanberg E, Müller-Loswick A-C, Matthews DE, Korner U, Andersson M \& Lundholm K (1996) Effects of amino acids on synthesis and degradation of skeletal muscle proteins in humans. American Journal of Physiology 271, E718-E724.

Szepesi B \& Freedland RA (1969) Time-course of enzyme adaptation II. The rate of change in two urea cycle enzymes. Life Sciences 8, 1067-1072.

Taillandier D, Aurousseau E, Meynial-Denis D, Becket D, Ferrara M, Cottin P, Ducastaing A, Bigaru X, Guezennec C-Y, Schmid H-P \& Attaix D (1996) Coordinated activation of lysosomal, $\mathrm{Ca}^{2+}$-activated and ATP-ubiquitin dependent proteinases in the unweighted psoas muscle. Biochemical Journal 316, 65-72.

Tessari P, Pehling G, Nissen SL, Gerich JE, Service FJ, Rizza RA \& Haywood MW (1988) Regulation of whole body leucine metabolism with insulin during mixed-meal absorption in normal and diabetic subjects. Diabetes 37, 512-519.

Toates FM (1975) Control Theory in Biology and Experimental Psychology. London: Hutchinson.

Tripathy K, Klahr S \& Lotero H (1970) Utilization of exogenous urea nitrogen in malnourished adults. Metabolism 19, $253-262$.

Tsuda M, Shikata Y \& Katsunuma T (1979) Effect of dietary proteins on the turnover of rat liver argininosuccinate synthetase. Journal of Biochemistry 85, 699-704.

Ulbright C \& Snodgrass PJ (1993) Coordinate induction of the urea cycle enzymes by glucagon and dexamethasone is accomplished by three different mechanisms. Archives of Biochemistry and Biophysics 301, 237-243.

Varcoe R, Halliday D, Carson ER, Richards P \& Tavill AS (1975) Efficiency of utilization of urea nitrogen for albumin synthesis by chronically uraemic and normal man. Clinical Science and Molecular Medicine 48, 379-391.

Varshavsky A (1992) The N-end rule. Cell 69, 725-735.

Varshavsky A (1996) The N-end rule: functions, mysteries, uses. Proceedings of the National Academy of Sciences, USA 93, $12142-12149$.

Vilstrup H (1980) Synthesis of urea after stimulation with amino acids: relation to liver function. Gut 21, 990-995.

Vilstrup H (1989) On urea synthesis - regulation in vivo. Danish Medical Bulletin 36, 419-429.

Walser M (1981) Urea metabolism. In Nitrogen Metabolism in Man, pp. 229-246 [JC Waterlow and JML Stephen, editors]. London: Applied Science Publishers.

Walser M \& Bodenlos L (1959) Urea metabolism in man. Journal of Clinical Investigation 38, 1617-1626.

Wanders DJA, Van Roermund CWT \& Meijer A (1984) Analysis of the control of citrulline synthesis in rat liver. European Journal of Biochemistry 142, 247-254.

Waterlow JC (1985) What do we mean by adaptation? In Nutritional Adaptation in Man, pp. 1-11 [K Blaxter and J C Waterlow, editors]. London: John Libbey.

Waterlow JC (1994) Emerging aspects of amino acid metabolism: Where do we go from here? Journal of Nutrition 124, $15245-15285$.

Waterlow JC (1995) Whole body protein turnover in humans: past, present and future. Annual Reviews of Nutrition 15,57-92.

Waterlow JC, Garlick PJ \& Millward DJ (1978) Protein Turnover in Mammalian Tissues and in the Whole Body. Amsterdam: North Holland.

Watford M (1989) Channelling in the urea cycle: a metabolism spanning two compartments. Trends in Biochemical Sciences 14, 313-314.

Weijs PJM, Calder AG, Milne E \& Lobley GE (1996) Conversion of $\left[{ }^{15} \mathrm{~N}\right]$ ammonia into urea and amino acids in humans and the effect of nutritional status. British Journal of Nutrition 76, 491-499.

Young VR \& Scrimshaw NS (1968) Endogenous nitrogen metabolism and plasma free amino acids in young adults given a 'protein-free' diet. British Journal of Nutrition 22, 9-20.

Young VR, Meredith C, Hoerr R, Bier DM \& Matthews DE (1985) Amino acid kinetics in relation to protein and amino acid requirements: the primary importance of amino-acid oxidation. In Substrate and Energy Metabolism in Man, pp. 119-133 [J S Garrow and D Halliday, editors]. London: John Libbey.

Young VR, Yang RD, Meredith C, Matthews DE \& Bier DM (1983) Modulation of amino acid metabolism by protein and energy intakes. In Amino Acids: Metabolism and Medical Applications, pp. 13-28 [GL Blackburn, JP Grant and VR Young, editors]. Bristol: John Wright.

You G, Smith CP, Kanai Y, Lee W-S Stelzner M \& Hediger MA (1993) Cloning and characterization of the vasopressin-regulated urea transporter. Nature (London) 365, 844-847.

Yu Y-M, Wagner DA, Tredget EE, Walaszewski JA, Burke JF \& Young VR (1990) Quantitative role of splanchnic region in leucine metabolism: L- $\left[1-{ }^{13} \mathrm{C}^{15} \mathrm{~N}\right]$ leucine and substrate balance studies. American Journal of Physiology 259, E36-E51. 